\title{
IMPROVING CHINA'S REGIONAL FINANCIAL CENTER MODERNIZATION DEVELOPMENT USING A NEW HYBRID MADM MODEL
}

\author{
Kuang-Hua HUa, Wei JIANGUOb ${ }^{\mathrm{b}}$, Gwo-Hshiung TZENG ${ }^{\mathrm{c}}$ \\ ${ }^{a}$ School of Accounting, Guangdong University of Finance and Economics, China \\ 21 Chisha Road, Haizhu District, Guangzhou 510320 PRC \\ ${ }^{b}$ Business School, Sun Yat-sen University, Guangzhou, China \\ ${ }^{b}$ Accounting School, Nanfang College of Sun Yat-sen University, Guangzhou, China \\ ${ }^{c}$ Graduate Institute of Urban Planning, College of Public Affairs, National Taipei University, Taiwan \\ Received 13 February 2015, accepted 08 December 2015
}

\begin{abstract}
The regional financial center is the propeller of regional economic development. Regional financial center modernization, however, has been the predominant propulsion of economic sustainability. Decisions related to regional financial center modernization development are inherent problems of multiple attribute decision-making (MADM), and strategically important to the government. The purpose of this paper is to set up a regional financial center improvement model for modernization development, as based on a hybrid MADM model, which addresses the main causal-effect factors and amended priorities in order to strengthen ongoing planning. This paper adopts a new hybrid MADM model combined with the DEMATEL technique to construct an influential network relationship map (INRM) and determined the influential weights of DANP. Then, a modified VIKOR method using influential weights is applied to measure and integrate the performance gaps from each criterion into dimensions, as well as the overall criterion for evaluating and improving the modernization development of the regional financial center, as based on INRM. Finally an empirical case study using data from the Guangzhou regional financial center is carried out as an example to demonstrate the suitability of the proposed hybrid MADM model for solving real-world problems. The results show the priorities for improvement, as based on the degree of the effect and impact of the dimensions, as follows: first is making "government policy", second is enforcing "financial infrastructure and safety", next is formulating "financial institutions and human resources", and finally "financial service".
\end{abstract}

Keywords: regional financial center, modernization development, improvement model, MADM (multiple attribute decision making), DEMATEL, INRM (influential network relation map), DANP (DEMATEL-based ANP), VIKOR.

JEL Classification: O160, O180, O380, R110, H110.

Corresponding author Kuang-Hua $\mathrm{Hu}$

E-mails: 18320709916@163.com; khhu0622@gmail.com 


\section{Introduction}

While regional economic development is the propeller of national economic growth, the regional financial center has been the central pillar of regional economic development. It clusters many financial institutions into a specific area to form a financial trading platform, and plays the role of an international financial bridge. A regional financial center offers comprehensive financial services to promote capital assemblage and accelerate financial depth and innovation, in order to enhance the country's economic strength. Luintel et al. (2008) found that financial structure and financial development significantly affect the output level of most countries. It is necessary to create a geography agglomeration of financial activities due to information problems, and a financial center could be its platform (Zhao et al. 2004). Cobb (1998) provided evidence that the global major financial centers, such as New York, London, and Tokyo, have good financial services. In spite of the representative international financial center, New York and other regional financial centers, which are established in the East, Central, and West in the US, including Washington, Chicago, Boston, Houston, Luoxia, and San Francisco, promote local economic operational quality and efficiency.

Whether an international financial center or a regional financial center, both are useful information exchange platforms, and can decrease information asymmetries and financing costs (De las Mercedes Adamuz, Cortés 2015); thereby increasing financial transactions and services (An et al. 2015). The changes of major global events, such as China's shift to a market economy and the founding of a single-market region in Europe, as well as a high degree of financial connectedness under globalization (Gao et al. 2015), have stimulated the growth of financial centers, and promoted the development of several new locations and the provision of more financial transactions and services to attract international business (Cetorelli, Peristiani 2013). Al-Salem and Mohammed (2012) indicated that an international financial center plays a dominant role in providing multi-financial services and agglomeration of financial institutions, which are competitive in global financial markets. When a dominant country is also a global financial center, it would expand the improvement of social welfare (Yu 2015). Farooq and El Ouadrhiri (2014) suggested that firms headquartered in a financial center have well-functioning information environments (Miller 2015) than other firms, via the clustering of firms, and significantly outperform dispersed firms during the crisis period. Jarvis (2011) claimed that the establishment of a financial center can support financial sector growth and maintain their competitiveness in emerging markets.

Regional financial centers depend on the major regional city, and are formed by financial factors and resources to assemble in a central city. In addition to providing economies of scale and speeding up self-growth, they also emerge as a strong radiative effect on neighbourhoods and provide innovative financial features. Hoening (1998) argued that the world of finance has changed dramatically, with banks' credit markets and payment system requirements through a network; thus, a secure internet implies financial modernization. Leach (2000) pointed out that financial service companies use new technologies to provide the best service to households and enterprises, and have financial regulatory reforms in alignment with financial institution modernization (Khan 1999). 
A comprehensive survey of the relative issues when discussing international/regional financial center modernization development by influential analysis mostly applied narrative presentations. Few studies adopted qualitative data, and some financial center modernization variables lack quantitative data available to experts with practical experience. Therefore, in order to fill the gap in literature for improving financial center modernization, and to promote the effectiveness and validity, this paper considers all related variables of the factors of regional financial center modernization development, as based on the empirical case of Guangzhou in China. This research focuses on the methods required to improve regional financial center modernization, thereby, stimulating regional economic development, and considering the existing/occurring inter-relationship problems among multiple criteria/ attributes for decision-making in realistic situations (Tzeng, Huang 2011, 2013; Liou, Tzeng 2012; Peng, Tzeng 2013). In recent years, several important new concepts and trends of the hybrid MADM (multiple attribute decision making) model for solving actual problems are considered. MADM is able to simultaneously consider multiple criteria/attributes, which help decision makers evaluate and estimate the best case, as based on the characteristics of a limited number of alternative cases, for application in ranking and selection (traditional approach), as well as for building performance improvement strategies (new approach), such as solving the three major problems of this research. First, the traditional MADM methods assumes the criteria/attributes are independently, linearly, and hierarchically structured; however, in reality, problems are often characterized by interdependent criteria/attributes, and may even show feedback-like effects for avoiding "some statistics and economics are unrealistic in the real world", such as, assumptions/hypotheses, etc.; second, relatively good solutions according to the max-min concept of existing alternatives are replaced by "aspiration levels" to satisfy contemporary social needs, and avoiding "picking the best apple among a barrel of rotten apples" (Simon incorporated the basic concept of the "aspiration level" in his work, and received the Nobel Prize in Economics in 1978); third, emphasis in the field has shifted from ranking/selection when determining the most preferable approaches to performance improvement of existing methods by systematics, as "we need a systematic approach to problem-solving; instead of addressing the systems of the problem, we need to identify the sources of the problem" for avoiding "stop-gap piecemeal" (Liou, Tzeng 2012; Liou 2013; Peng, Tzeng 2013). Thus, this paper seeks a hybrid multiple attribute decision-making (MADM) model combining the decision-making trial and evaluation laboratory (DEMATEL) technique to construct a total influence-relation matrix by dimensions and criteria for constructing an influential network relation map (INRM) to solve real-world problems using natural language to identify the degree of effects from the different dimensions/criteria. Then, the basic concept of the analytic network of process (ANP) was used to determine the influential weights of DEMATEL-based ANP (DANP) by using the total influence relation matrix of DEMATEL. Finally, the modified VIKOR (VlseKriterijumska Optimizacija I Kompromisno Resenje) method, using the influential weights of DANP as integration-weighting, was used to assess and improve the performance gaps. In addition to being used for ranking and selection, it could also be used for providing innovating/creating regional financial center modernization improvement strategies, as based on INRM, to reduce the gaps near to zero in each dimension and criterion, and then, for promoting efficiency and satisfying social needs in regional financial services. 
The remainder of this paper is organized, as follows. Section 1 briefly introduces the assessed dimensions and criteria in related literature; Section 2 discusses the analytical framework and methods for constructing a regional financial center modernization evaluation system; Section 3 proposes an empirical case of an improvement plan for Guangzhou regional financial center modernization; Section 4 offers conclusions.

\section{Related literature}

During this era of globalization, information technology, and market-orientation, finance has been at the core of modern economies. Countries and firms with higher levels of financial market development have more external finance and growth opportunities, which benefit economic development (Fase, Abma 2003; Bena, Ondko 2012). Boehne (2000) indicated that a well-functioning financial system is the robust core of a strong economy, and consumer confidence is the underpinning of a successful financial system. Over the last two decades, the Chinese government has guided rapid modernization and transformation of its banking system, and increased its power on the global stage (Rana 2012). When building a modern regional financial center, sound software and hardware are indispensable. The many kinds of variables related to regional financial center modernization can be grouped into four categories.

\subsection{Government policy}

A financial incentive system has been recommended as the means of foreign direct investment (FDI) inducement, and balances regional economic development in reaction to the demands of local governments. If government supports the goals of the firms and customizes their FDI incentives, they will attract much more foreign capital (Lim 2005). Deng et al. (2012) claimed that tax incentives have been utilized worldwide to attract FDI; however, the productivity spill over effects of FDI can elevate GDP, national output, and welfare. Special tax incentive zones in China implemented concessionary tax rates and incentives, which are effective in attracting FDI (Tung, Cho 2000). In order to attract or retain businesses, many American communities provide tax abatements or tax credits to enterprises, particularly lower-income communities; however, state governments also face a trade-off between business and tax revenue (Felix, Hines Jr. 2013). Thakor (2012) showed that financial innovation incentives and increasing the amount of innovation generate profit based on innovation loans, which help to lower entry costs. In addition, the greater the transparency of the balance sheets of financial institutions, the less effect from financial crisis on innovation and the less loan-related profit for banks. Gertler et al. (2012) indicated that a government credit policy during a crisis affects the exposure of the financial system.

Financial regulations should not only focus on the bank sector, but also monitor the development of stock markets, especially in emerging markets. Emerging markets mainly use bank-based financial systems, and are not market-based, which requires more time to recover from economic downturns after a financial crisis (Baum et al. 2011; Allen et al. 2012). Since the late 1980s, there have been structural changes, as well as the openness of domestic financial markets in emerging economies. Higher credit and equity market integration decrease the cost of capital, and reflect the economic benefits brought by financial 
integration. Enterprises enjoy the positive outcomes of financial integration, which are lower monitoring costs, more transparent information, and better creditor and shareholder protection (Lucey, Zhang 2011). However, while the openness of financial markets contribute to the development of financial centers, in the face of financial instability in the international environment, financial supervision and regulation are increasingly important. Klomp and Haan (2012) used 200 banks from 21 OECD countries, and found that supervisory control, capital regulations, and market entry regulations all exert significant impacts on capital and asset risk; and banking norms and supervision of each country differ in regard to banking risks. Buck and Schliephake (2013) also posited that minimum capital requirements and the supervision of domestic banks involve a trade-off: higher capital requirements decrease banks' profitability. Strict supervision causes a reduction in banks' vulnerability to collapse, thus, it is essential that supervision is in line with international standards and harmonizing regulations. Barth et al. (2013) clarified that banking regulations, supervision, and market monitoring have significant effect on bank efficiency, implying that there is a potential tradeoff between bank safety and efficiency, and that information disclosure and external auditor requirements are positively associated with banks' operational efficiency.

Centralization and optimal allocation of financial resources reduce trade costs, improve transaction efficiency, and promote the operation of regional economies. Doh and Kim (2014) suggested that governments provide financial support for regional small and medium enterprise (SME) innovations, and state that there is a positive relationship between the technological development assistance of the government and new design registrations of regional SMEs. Guan and Yam (2015) maintained that the centrally-planned funding system was ineffective in enhancing technological advances for Chinese manufacturing firms in the 1990s. While direct earmarks did not have significant effect in improving economic performance; they had negative impact on business innovation. However, the incentive systems of tax credits and special loans contribute to promoting firms' innovation capacity in China.

\subsection{Financial infrastructure and safety}

The financial infrastructure is the cornerstone of financial market development, and convenient transportation and well-developed infrastructure provide the most basic external conditions for financial agglomeration; cross-country enterprises and financial institutions entry will depend on these factors. Under these terms, savings can be effectively mobilized within productive capital, and channelled to the most productive uses, in order to optimize the development of financial markets (Moskow 2002). Whittaker (2002) claimed that financial systems facilitate investment, and support banking and services to customers, with all of these contributing directly and indirectly to the national GDP, thus, they should be considered as a chief element of critical national infrastructure. Amable and Chatelain (2001) emphasized that strong financial infrastructure can enhance the efficiency of banks (Von Furstenberg, Fratianni 1996), such as decreasing the market power of financial intermediaries, lowering the cost of capital, and increasing the number of depositors; thereby promoting economic growth.

Financial ecological environments include the legal system, social honesty and credit, accounting and auditing standards, the intermediary service system, the relationship between 
banks and firms, etc. Muniandy and Ali (2012) proposed that accounting practices are influenced by legal, political, and cultural aspects, as well as the capital market. If the accounting regulatory system of a country has been internationally accepted, it can assist the favourable process of international trade (Saudagaran, Diga 2000). Strict regulations on bank entry, limitations on bank activities, and repressing banks' conducting their business, all raise the cost of financial intermediation and have detrimental effect on financial development (Demirgüç-Kunt et al. 2003). Manson and Zaman (2001) stated that, while an audit report strengthens the believability of financial statements, the users of financial statements care more about the auditors' assessment of the going concern of the firm, and whether or not fraudulent or illegal acts emerge from the auditors' findings. Based on the above, this paper suggests that the financial ecological environment may be the prime criterion triggering regional financial center modernization.

Giannetti and Jentzsch (2013) illustrated that credit reporting systems are a critical part of financial markets, and that the borrowers' identification system has positive effective on financial intermediation and financial access. According to Treacy and Carey (2000), most large banks in the U.S. have internal rating systems, which are increasingly important in dealing with credit risks. With the changing financial environment, designing appropriate rating systems promotes their effectiveness. While credit cards have become the most popular means of payments around the world, they introduce credit risks for financial institutions, thus, building fraud detection systems has also been a development trend (Leonard 1995; Pavía et al. 2012). In addition, small enterprises are seriously affected by economic downturn, as they generate more credit risks due to changing business environments. Tsaih et al. (2004) commented that a credit scoring decision support system for small business loans can be easily modified to deal with the changing business environment. Tsai et al. (2011) noted that banks prefer to enter countries that have private credit bureaus or higher quality credit reporting systems, as they can reduce their information costs and obtain better quality information from the credit database (Brown, Zehnder 2010).

Since the development and application of the internet and computers, information systems play an increasingly vital role in business operations (Kankanhalli et al. 2003). Laws, regulations, new threats, and business objectives are all drivers, and information security risk management of business is paramount (Jirasek 2012), particularly in the finance industry. Luo (2011) cited many problems of information security in China, such as network security among enterprises, attacks on the fragile e-government system, a shortage of information security professionals, leaders lacking awareness of information security, and the imperfections of the relevant laws and regulations. The risk assessment of information security has started in China; thus, building and improving the foundation of risk assessment, enhancing information security risk assessment teams, and cultivating information security professionals are urgent and important (Fu, Xiao 2011; Zhiwei, Zhongyuan 2012).

\subsection{Financial service}

The loan market is a crucial part of financial center development, and international shocks are extensively disseminated through cross boarder credit markets (Giannetti, Laeven 2012). 
Longstaff (2010) also considered that financial contagion is propagated in cross-markets with significant effect. In the early stages of economic development, a well-functioning credit market could assist the poor to accumulate wealth. Agostino et al. (2010) found that with energetic competition, local credit markets might stimulate banks to perform more accurate screening of borrowers/SMEs, in order that credit market competition raises the assigned efficiency of bank funds. With lower credit market friction in countries, financial reforms have reduced flaws, which lead to a decline in macroeconomic volatility (Cavalcanti 2010) and enhance stable economic development. In recent years, the barriers on foreign bank entry and activity have been largely cut in many countries, and the loan proportion from foreign banks has also gradually increased (Haselmann, Wachtel 2011), implying more extensive financial services.

Baum et al. (2011) stated that financial architecture plays a key role in SMEs by influencing the levels of financial development and economic growth. Ndikumana (2005) reported that when a country has a well-developed financial system, investing is easier with lower finance costs, which effectively elevates the level of domestic investment and long-term economic growth. Underdeveloped and imperfect financial markets might be globally excluded, and the information will not be smoothly propagated in cross-country communication (Yartey 2008). Bolbol et al. (2005) found that the development of financial structure consists of three issues: speeding the privatization of state business, widening foreign inflows, and stock market reforms, which contribute to domestic economic growth. Building a national financial market trading platform locally can optimize the allocation of financial resources, strengthen the radiation and influence of regional financial centers, and form the advantages and power of the finance industry. Building world-famous commercial city centers, such as the City of London, and Wall Street in New York City, enhance international visibility.

\subsection{Financial institutions and human resources}

Financial institutions are a cardinal brace in the construction of a regional financial center, and promote the comprehensive strength and competitiveness of the financial center, especially for large financial institutions and new entries. To avoid financial crises recurring, financial reform policies in Thailand particularly allowed greater foreign bank penetration; and an effective and stable financial system could be established (Thakor 2012). Okuda and Rungsomboon (2006) also presented that foreign and domestic banks have different functions; the former have advanced screening and monitoring techniques and experienced risk management skills to service multinational companies and large Thai companies, while the latter provides domestic service to SMEs and households. The introduction of large foreign financial institutions boosts the level of financial development. The higher the level of financial institutions, the more superior the economic growth (Bekaert et al. 2005). Luo (2012) was convinced that capital market development is regarded as the pivotal aspect of a city's financial center, including the number of firms listed, the number of securities listed, and the depth of market capitalization. A financial center in a central city involves the coexistence of financial institutions and large numbers of professional services, thus, it must be supported by talents. Balan and Knack (2012) indicated that professional's morality and ability are associated 
with higher per-capital incomes, and influence aggregate economic performance; moreover, CEOs' ethical leadership is an important factor for top management team effectiveness (De Hoogh, Den Hartog 2008).

Based on literature review, as noted above, and according to interviews with five government officials in the Guangdong Office, China Banking Regulatory Commission, three scholars in finance-related departments, and four managers from banks; based on literature review and through a pre-test questionnaire for choosing important criteria, the results as the following four perspectives (dimensions) and 21 affiliated criteria of influence are as shown in Table 1. The 21 criteria form the basis of the pre-test questionnaire for Guangzhou regional financial center modernization development.

Table 1. The performance evaluation factors for the pre-test questionnaire

\begin{tabular}{|c|c|c|c|}
\hline \multicolumn{4}{|c|}{ Perspectives (or called Dimensions) } \\
\hline Government policy & $\begin{array}{c}\text { Financial } \\
\text { infrastructure and } \\
\text { safety }\end{array}$ & Financial service & $\begin{array}{c}\text { Financial institutions } \\
\text { and human } \\
\text { resources }\end{array}$ \\
\hline $\begin{array}{l}\text { Criteria } \\
\text { Financial liberalization } \\
\text { Financial regulations } \\
\text { modernization } \\
\text { Financial industry } \\
\text { development policy } \\
\text { Financial supervision } \\
\text { and regulation } \\
\text { Allocation of financial } \\
\text { resources }\end{array}$ & $\begin{array}{l}\text { Financial } \\
\text { infrastructure } \\
\text { Financial ecological } \\
\text { environment } \\
\text { Financial street } \\
\text { Credit systems } \\
\text { Electronic financial } \\
\text { and information } \\
\text { safety }\end{array}$ & $\begin{array}{l}\text { Credit market } \\
\text { Financial structure } \\
\text { National financial } \\
\text { market trading } \\
\text { platform } \\
\text { Financial capital } \\
\text { management } \\
\text { The diversification of } \\
\text { the financial products } \\
\text { The quality of the } \\
\text { financial products }\end{array}$ & $\begin{array}{l}\text { Large financial } \\
\text { institutions } \\
\text { New financial } \\
\text { institutions } \\
\text { Listed financial } \\
\text { enterprises } \\
\text { Cultivating financial } \\
\text { professionals } \\
\text { Financial employees' } \\
\text { morality }\end{array}$ \\
\hline
\end{tabular}

\section{Building a new hybrid MADM model for improving regional financial center modernization development}

The MADM model is developed based on the abovementioned studies, and is selected as a fitting method for the assessment of regional financial center modernization development; decision-makers can use the outcome for improving and reducing the performance gaps in each criterion. This section includes four sub-sections: first, the data collection process is as illustrated in Subsection 2.1; the DEMATEL technique is introduced; and information of how to build an influential network relation map (INRM) is proposed in subsection 2.2; the next chapter discusses how to find the influential weights of DANP, as based on the total influence relation matrix of the DEMATEL technique in Subsection 2.3; finally, application of the modified VIKOR method transforms the performance values into normalized performance gaps, as based on aspiration-worst level, is presented in Subsection 2.4. The research processes are illustrated in Figure 1. 


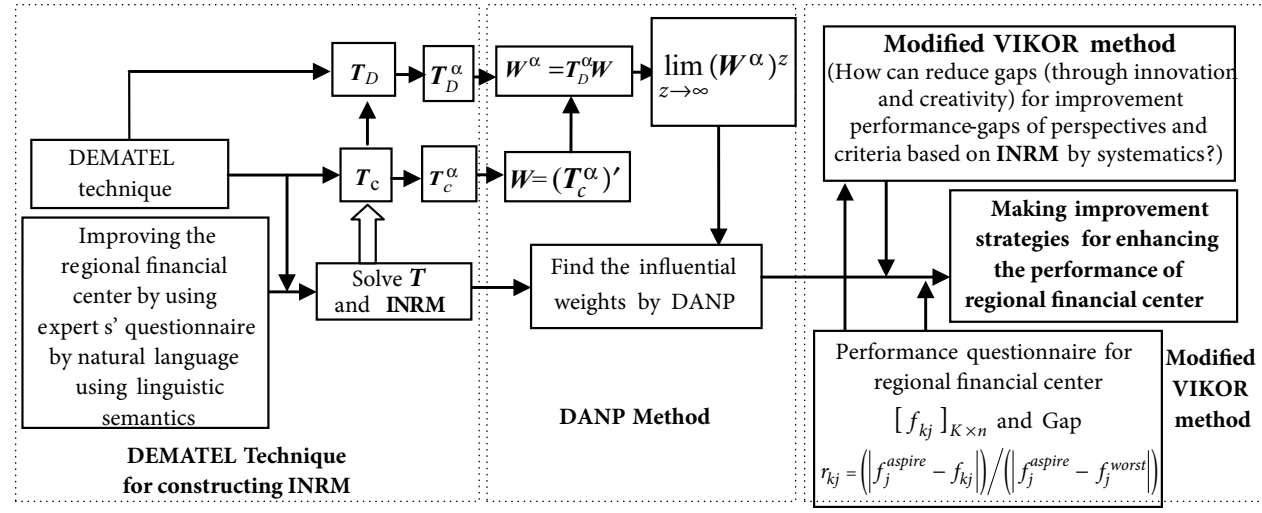

Fig. 1. Model procedure for new multiple attribute decision making for the regional financial center modernization

\subsection{Data collection}

The research sample was collected from professional personnel and scholars who have a deep knowledge of the regional financial center (i.e., refers to the experts in practical experience), through in-depth interviews and questionnaire surveys. The researchers collected the viewpoints of experts regarding the effects of the evaluation criteria of the four dimensions, as described above, on the modernization development of a regional financial center; 30 questionnaire experts were assigned in the second phase, including 12 government officials from the Guangdong office, China Banking Regulatory Commission, 10 presidents or managers from financial institutions, and 8 university scholars in finance-related departments. Each interview took 60-90 minutes. In the first phase (pre-test questionnaire), the potential factors affecting the modern development of the Guangzhou regional financial center are listed. These factors were compiled based on existing studies and expert opinions to select the most important factors (important scales based on triangular fuzzy numbers, with a mean scoring of 8 point and above in range-scales from 0 to 10 points). The important scales were preserved to facilitate the design of the second phase questionnaire, which was followed by further selection, with the results elaborated in Table 2. The results were subject to empirical analysis, as based on research methodology stated herein. In light of experts' opinions, the questionnaires assessed the relationship between mutually influential criteria, with a scale ranging from 0 to 4 points, where scores represented a range from "completely no influence (0)" to "very high influence (4)". Respondents proposed the degree of direct influence that each perspective (dimension) and criterion (factors) exerts on another perspective and criterion. The DEMATEL technique was used to analyze the data from the questionnaires to reveal the relationships among the perspectives and criteria (Appendix B3.1 and B3.2). 
Table 2. Regional financial center modernization evaluation factors

\begin{tabular}{|c|c|c|}
\hline Dimensions/Criteria & Descriptions & References \\
\hline \multicolumn{3}{|c|}{ Government policy $(A)$} \\
\hline $\begin{array}{l}\text { Financial industry } \\
\text { development policy } \\
\left(a_{1}\right)\end{array}$ & $\begin{array}{l}\text { Include the financial incentive } \\
\text { system, tax abatements or tax } \\
\text { credits for enterprises promoted by } \\
\text { Guangzhou government; }\end{array}$ & $\begin{array}{l}\text { Deng et al. (2012); Felix and } \\
\text { Hines Jr. (2013); Gertler et al. } \\
\text { (2012); Thakor (2012); Tung and } \\
\text { Cho (2000) }\end{array}$ \\
\hline $\begin{array}{l}\text { Financial supervision } \\
\text { and regulation }\left(a_{2}\right)\end{array}$ & $\begin{array}{l}\text { Financial administrative authorities } \\
\text { monitoring financial transactions } \\
\text { and maintaining financial market } \\
\text { stability; }\end{array}$ & $\begin{array}{l}\text { Allen et al. (2012); Barth et al. } \\
\text { (2013); Baum et al. (2011); Buck } \\
\text { and Schliephake (2013); Klomp } \\
\text { and Haan (2012); Lucey and } \\
\text { Zhang (2011) }\end{array}$ \\
\hline $\begin{array}{l}\text { Allocation of financial } \\
\text { resources }\left(a_{3}\right)\end{array}$ & $\begin{array}{l}\text { The central and local governments } \\
\text { inject funds into the financial sector. }\end{array}$ & $\begin{array}{l}\text { Doh and Kim (2014); Guan and } \\
\text { Yam (2015) }\end{array}$ \\
\hline \multicolumn{3}{|c|}{ Financial infrastructure and safety $(B)$} \\
\hline $\begin{array}{l}\text { Financial } \\
\text { infrastructure }\left(b_{1}\right)\end{array}$ & $\begin{array}{l}\text { Include convenient transportation } \\
\text { and communication, and good capital } \\
\text { flow environment; }\end{array}$ & $\begin{array}{l}\text { Moskow (2002); Whittaker } \\
(2002)\end{array}$ \\
\hline $\begin{array}{l}\text { Financial ecological } \\
\text { environment }\left(b_{2}\right)\end{array}$ & $\begin{array}{l}\text { Refers to the legal system, the social } \\
\text { honesty and credit, the accounting } \\
\text { and auditing standards, the } \\
\text { intermediary service system and the } \\
\text { relationship between banks and firms; }\end{array}$ & $\begin{array}{l}\text { Demirgüç-Kunt et al. (2003); } \\
\text { Manson and Zaman (2001); } \\
\text { Muniandy and Ali (2012); } \\
\text { Saudagaran and Diga (2000) }\end{array}$ \\
\hline Credit systems $\left(b_{3}\right)$ & $\begin{array}{l}\text { Build division and enterprise credit } \\
\text { systems; establish financial credit } \\
\text { infrastructure and systems; construct } \\
\text { credit records, credit evaluation, } \\
\text { credit monitoring, credit information } \\
\text { disclosure and penalization systems, } \\
\text { etc.; }\end{array}$ & $\begin{array}{l}\text { Brown and Zehnder (2010); } \\
\text { Giannetti and Jentzsch (2013); } \\
\text { Leonard (1995); Pavía et al. } \\
\text { (2012); Treacy and Carey (2000); } \\
\text { Tsai et al. (2011); Tsaih et al. } \\
\text { (2004) }\end{array}$ \\
\hline $\begin{array}{l}\text { Electronic financial } \\
\text { and information } \\
\text { safety }\left(b_{4}\right)\end{array}$ & $\begin{array}{l}\text { Enhance electronic financial } \\
\text { transaction information security. }\end{array}$ & $\begin{array}{l}\text { Fu and Xiao (2011); Jirasek } \\
\text { (2012); Kankanhalli et al. } \\
\text { (2003); Luo (2011); Zhiwei and } \\
\text { Zhongyuan (2012) }\end{array}$ \\
\hline \multicolumn{3}{|c|}{ Financial service $(C)$} \\
\hline Credit market $\left(c_{1}\right)$ & $\begin{array}{l}\text { Found a perfect credit market, such } \\
\text { as loan institutions to SMEs; }\end{array}$ & $\begin{array}{l}\text { Agostino et al. (2010); Cavalcanti } \\
\text { (2010); De las Mercedes Adamuz } \\
\text { and Cortés (2015); Giannetti and } \\
\text { Laeven (2012); Haselmann and } \\
\text { Wachtel (2011); Miller (2015) }\end{array}$ \\
\hline $\begin{array}{l}\text { Financial structure } \\
\left(c_{2}\right)\end{array}$ & $\begin{array}{l}\text { Whether or not Guangzhou financial } \\
\text { industry (banking, insurance and } \\
\text { security) development is unbalanced; }\end{array}$ & Baum et al. (2011); Yartey (2008) \\
\hline $\begin{array}{l}\text { National financial } \\
\text { market trading } \\
\text { platform }\left(c_{3}\right)\end{array}$ & $\begin{array}{l}\text { Establish a national financial market } \\
\text { trading platform, such as the } \\
\text { Guangzhou trade center in financial } \\
\text { assets and foreign exchange market. }\end{array}$ & $\begin{array}{l}\text { An et al. (2015); Bolbol et al. } \\
(2005)\end{array}$ \\
\hline
\end{tabular}


End of Table 1

\begin{tabular}{lll}
\hline & \multicolumn{2}{l}{ Financial institutions and human resources $(\boldsymbol{D})$} \\
\hline $\begin{array}{l}\text { Large financial } \\
\text { institutions }\left(d_{1}\right)\end{array}$ & $\begin{array}{l}\text { Establish global and domestic } \\
\text { influential financial institutions } \\
\text { or introduce foreign financial } \\
\text { institutions; }\end{array}$ & $\begin{array}{l}\text { Okuda and Rungsomboon } \\
(2006) ; \text { Thakor (2012) }\end{array}$ \\
\hline $\begin{array}{l}\text { New financial } \\
\text { institutions }\left(d_{2}\right)\end{array}$ & $\begin{array}{l}\text { Set up a variety of new financial } \\
\text { institutions; }\end{array}$ & Luo (2012) \\
\hline $\begin{array}{l}\text { Listed financial } \\
\text { enterprises }\left(d_{3}\right)\end{array}$ & $\begin{array}{l}\text { Increase the number of finance- } \\
\text { related companies listed in } \\
\text { Guangzhou; }\end{array}$ & Luo (2012) \\
\hline $\begin{array}{l}\text { Financial employees' } \\
\text { morality }\left(d_{4}\right)\end{array}$ & $\begin{array}{l}\text { The quality and morality of financial } \\
\text { professionals include CEO, managers } \\
\text { and the staff. }\end{array}$ & $\begin{array}{l}\text { De Hoogh and Den Hartog } \\
\text { (2008); Balan and Knack (2012) }\end{array}$ \\
\hline
\end{tabular}

\subsection{DEMATEL technique}

The DEMATEL technique was first developed by the Geneva Research Centre (Fontela, Gabus 1976) for the purpose of showing a network relation diagram, and a structural model for understanding specific societal problems. These basic concepts were used to create a series of new hybrid MADM models for solving complex and dynamic real world problems (Peng, Tzeng 2013; Tzeng, Huang 2012; Lu et al. 2013, 2015; Hu et al. 2015; Chen, Chi 2015; Liou et al. 2014, 2016). The DEMATEL technique involves three steps, detailed as follows.

Step 1: Calculate the direct influence relation average matrix $\boldsymbol{B}$. Assume the number of experts $H$ and the number of criteria $n$ are asked to propose that the pairwise comparisons between any two criteria are denoted by, and are given, an integer score of $0,1,2,3$, or 4 , expressing the range from "absolutely no influence (0)" to "very high influence (4)" by natural language in linguistics (e.g., semantics), and showing the degree that each criterion $i$ affects each criterion $j$. The answers by each expert form a $n \times n$ non-negative matrix $\boldsymbol{X}^{h}=\left[x_{i j}^{h}\right]_{n \times n}$, $h=1,2, \ldots, H$, where $\boldsymbol{X}^{1}, \ldots, \boldsymbol{X}^{h}, \ldots, \boldsymbol{X}^{H}$ are the answer matrices by the $H$ experts in practical experience, and the elements of $\boldsymbol{X}^{h}$ are denoted by $x_{i j}^{h}$ from expert $h$. Thus, an $n \times n$ average matrix $\boldsymbol{B}$ of all experts given can be built by Eq. (1):

$$
\boldsymbol{B}=\left[\begin{array}{ccccc}
b_{11} & \cdots & b_{1 j} & \cdots & b_{1 j} \\
\vdots & & \vdots & & \vdots \\
b_{i 1} & \cdots & b_{i j} & \cdots & b_{i n} \\
\vdots & & \vdots & & \vdots \\
b_{n 1} & \cdots & b_{n j} & \cdots & b_{n n}
\end{array}\right] .
$$

The average scores of the $H$ experts are $b_{i j}=\frac{1}{H} \sum_{h=1}^{H} x_{i j}^{h}$. The average matrix is called the initial direct relation matrix $\boldsymbol{B}$, and represents the degree of influence one criterion exerts on another, as well as the degree of influence it receives from other criteria.

Step 2: Normalize the initial direct influence relation matrix. The normalized initial direct influence relation matrix $\boldsymbol{D}$ is acquired by normalizing the average matrix $\boldsymbol{B}$. The matrix $\boldsymbol{D}$ is easily derived from Eqs. (2) and (3), whereby all principal diagonal criteria are equal to zero: 


$$
s=\min \left\{\frac{1}{\max _{1 \leq i \leq n} \sum_{j=1}^{n} b_{i j}}, \frac{1}{\max _{1 \leq j \leq n} \sum_{i=1}^{n} b_{i j}}\right\} .
$$

Step 3: Derive the total influence-relation matrix $\boldsymbol{T}$. A continuous decrease of the indirect effects of problems moves with the powers of the matrix $\boldsymbol{D}$, e.g. $\boldsymbol{D}^{2}, \boldsymbol{D}^{3}, \ldots, \boldsymbol{D}^{\infty}$, and $\lim _{q \rightarrow \infty} \boldsymbol{D}^{q}=[0]_{n \times n}$, for $\lim _{q \rightarrow \infty}\left(\boldsymbol{I}+\boldsymbol{D}+\boldsymbol{D}^{2}+\ldots+\boldsymbol{D}^{q}\right)=(\boldsymbol{I}-\boldsymbol{D})^{-1}$, where $\boldsymbol{I}$ is a $n \times n$ unit matrix. The total influence relation matrix $\boldsymbol{T}$ is a $n \times n$ matrix, and is defined by $\boldsymbol{T}=\left[t_{i j}\right]_{n \times n}, i, j=1,2, \ldots, n$ as shown in Eq. (4):

$$
\begin{aligned}
\boldsymbol{T} & =\boldsymbol{D}+\boldsymbol{D}^{2}+\ldots+\boldsymbol{D}^{q} \\
& =\boldsymbol{D}\left(\boldsymbol{I}+\boldsymbol{D}+\boldsymbol{D}^{2}+\ldots+\boldsymbol{D}^{q-1}\right) \\
& =\boldsymbol{D}\left(\boldsymbol{I}+\boldsymbol{D}+\boldsymbol{D}^{2}+\ldots+\boldsymbol{D}^{q-1}\right)(\boldsymbol{I}-\boldsymbol{D})(\boldsymbol{I}-\boldsymbol{D})^{-1} \\
& =\boldsymbol{D}(\boldsymbol{I}-\boldsymbol{D})^{-1}, \text { when } \lim _{q \rightarrow \infty} \boldsymbol{D}^{q}=[0]_{n \times n} .
\end{aligned}
$$

The total influence relation matrix $\boldsymbol{T}$ of INRM can be acquired by Eq. (4). Eqs. (5) and (6) are used to generate each row sum and column sum in the matrix $T$, respectively:

$$
\begin{gathered}
\boldsymbol{d}=\left(d_{i}\right)_{n \times 1}=\left[\sum_{j=1}^{n} t_{i j}\right]_{n \times 1}=\left(d_{1}, \ldots, d_{i}, \ldots, d_{n}\right)^{\prime} ; \\
\boldsymbol{r}=\left(r_{j}\right)_{n \times 1}=\left(r_{j}\right)_{1 \times n}^{\prime}=\left[\sum_{i=1}^{n} t_{i j}\right]_{1 \times n}^{\prime}=\left(r_{1}, \ldots, r_{j}, \ldots, r_{n}\right)^{\prime},
\end{gathered}
$$

where $d_{i}$ is the sum of a row in the total influence relation matrix $T$, which represents the total effects (both direct and indirect) of criterion/perspective $i$ on the all other criteria/perspectives $\left[\sum_{j=1}^{n} t_{i j}\right]_{n \times 1}$. Similarly, $r_{j}$ is the column sum in the total influence relation matrix $\boldsymbol{T}$, which represents the total effects (both direct and indirect) of criterion/perspective $j$ received from the all other criteria/perspectives $\left[\sum_{i=1}^{n} t_{i j}\right]_{1 \times n}$. Thus, when $i=j,\left(d_{i}+r_{i}\right)$ offers an index of the strength of the total influences given and received, that is $\left(d_{i}+r_{i}\right)$ indicates the degree of importance that criterion/perspective $i$ plays in the system. In addition, $\left(d_{i}-r_{i}\right)$ provides an index of the degree of the cause of total influence. If $\left(d_{i}-r_{i}\right)$ is positive, then criterion/perspective $i$ is a net causer, and if $\left(d_{i}-r_{i}\right)$ is negative, then criterion/perspective $i$ is a net receiver.

\subsection{Based on the DEMATEL technique to find the influential weights of DANP}

Besides using DEMATEL to identify the inter-relationships between the fourteen factors, this study also attempted to obtain more precise "influential weights" in line the real world problem. "Influential weights of DANP (DEMATEL-based ANP)" is in line with the needs for solving practical issues to relax or relieve some unreasonable assumptions in AHP and ANP. Saaty (1996) proposed an ANP to solve the dependence and feedback problems only between dimensions (or called clusters), criteria (inner dimension/cluster) in diagonal matrix until assumed to be independent (zero matrix, $\boldsymbol{W}^{i i}=[0]$ ) or assumed self-relation (Iden- 
tity matrix, $\boldsymbol{I}$ ), and the weighted super-matrix obtained by using equal weights. This ANP overcomes the limitations of the Analytic Hierarchy Process (AHP) that assuming criteria (inner and outer dimension/cluster) to be all independent. The difference of the two methods is that ANP can be applied to the decision-making problems of the interrelationship in outer dimensions (or called clusters), while AHP assumes the independent relationship between outer and inner dimensions (i.e., all dimension and criteria). If there exists an influential interrelationship between dimensions/criteria that is not taken into account, it could affect the outcome of the decision. Therefore, this study used a new hybrid MADM model for improving the modernization development of China's regional financial center, and adopted DEMATEL technique via knowledge domain of experts in practical experience, in order to build influence relation matrix for constructing influential network relation (INRM) and determining the influential weights of DANP (DEMATEL-based ANP) based on the basic concept of ANP (Saaty 1996). The aim is to solve those problems (Chen, Tzeng 2015) that resemble real world problems, in instead of traditional applications. Thus, the influential weights of DANP (DEMATEL-based ANP) contain the following steps.

Step 4: Total influence relation matrix $\boldsymbol{T}_{C}$. DEMATEL is used to build total influence relation matrix $\boldsymbol{T}_{C}$ from each perspective (dimension or cluster), with different degrees of influence relation for the criteria, as shown in Eq. (7), where $\sum_{j=1}^{m} m_{j}=n, m<n$, and $\boldsymbol{T}_{c}^{i j}$ as a $m_{i} \times m_{j}$ matrix:

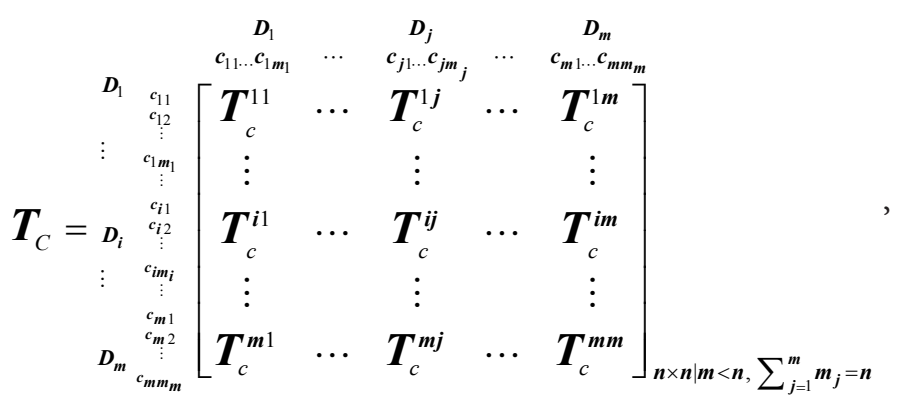

where $D_{m}$ is the $m$ th cluster; $c_{m m}$ is the $m$ th criterion in the $m$ th dimension; and $\boldsymbol{T}_{C}^{i j}$ is a submatrix of the influence relation by the criteria from a comparison of the $i$ th dimension and the $j$ th dimension. In addition, if the $i$ th dimension has no influence on the $j$ th dimension, then submatrix $\boldsymbol{T}_{C}^{i j}=[0]$, shows independence (no influence relation) in each other criterion.

Step 5: Form an un-weighted super-matrix $\boldsymbol{Y}$. Normalize the total influence relation matrix $\boldsymbol{T}_{C}$ as shown in Eq. (8):

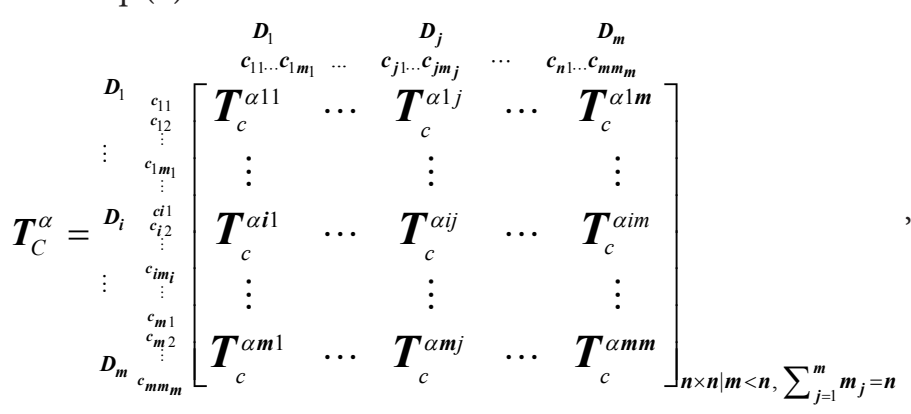


where $\boldsymbol{T}_{C}^{\alpha}$ denotes the normalizing total influence relation matrix, and $\boldsymbol{T}_{c}^{\alpha 14}$ is derived from Eqs. (9) and (10). Similarly, $\boldsymbol{T}_{c}^{\alpha m m}$ can be obtained:

$$
\begin{aligned}
& t_{i}^{14}=\sum_{j=1}^{m_{4}} t_{i j}^{14}, i=1,2, \cdots, m_{1} ;
\end{aligned}
$$

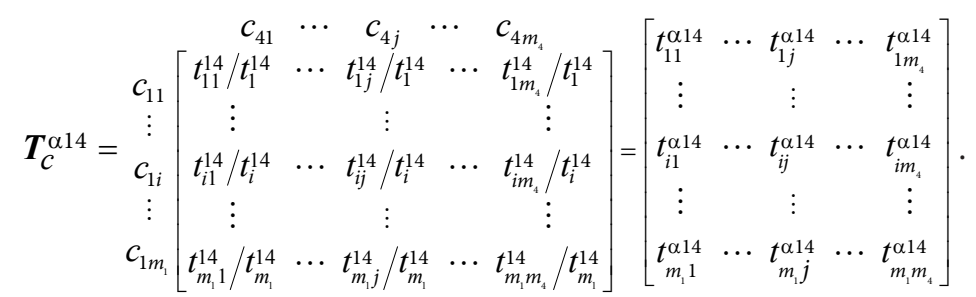

According to the pair-wise comparisons with the criteria, and based on the basic concept of ANP, the un-weighted super-matrix $W$ can be obtained by transposing the normalized influence-relation matrix $\boldsymbol{T}_{C}^{\alpha}$ by dimensions (clusters), i.e. $\boldsymbol{W}=\left(\boldsymbol{T}_{C}^{\alpha}\right)^{\prime}$, as shown in Eq. (11):

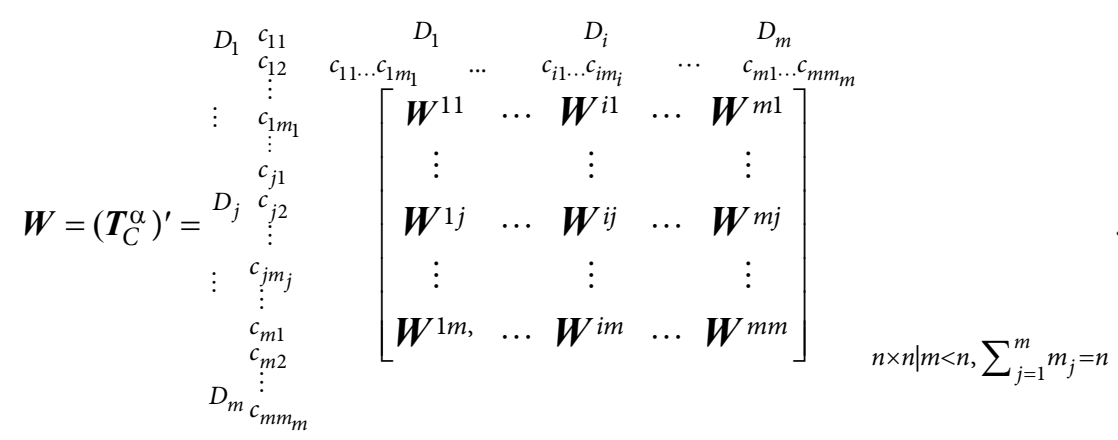

Step 6: Obtain the weighted super-matrix $\boldsymbol{W}^{\alpha}$. The total influence-relation matrix $\boldsymbol{T}_{D}$ of dimensions is derived according to the DEMATEL technique, as given by Eq. (12):

$$
\boldsymbol{T}_{D}=\left[\begin{array}{ccccc}
t_{11} & \cdots & t_{1 j} & \cdots & t_{1 m} \\
\vdots & & \vdots & & \vdots \\
t_{i 1} & \cdots & t_{i j} & \cdots & t_{i m} \\
\vdots & & \vdots & & \vdots \\
t_{m 1} & \cdots & t_{m j} & \cdots & t_{m m}
\end{array}\right]_{m \times m}
$$

The normalized total influence-relation matrix $\boldsymbol{T}_{D}^{\alpha}$ of dimensions can be obtained through the total influence-relation matrix $\boldsymbol{T}_{D}$ divided by $d_{i}=\sum_{j=1}^{m} t_{i j}, i=1,2, \ldots, m$, as shown in Eq. (13):

$$
\boldsymbol{T}_{\mathrm{D}}^{\alpha}=\left[\begin{array}{ccccc}
t_{11} / d_{1} & \cdots & t_{1 j} / d_{1} & \cdots & t_{1 m} / d_{1} \\
\vdots & & \vdots & & \vdots \\
t_{i 1} / d_{i} & \cdots & t_{i j} / d_{i} & \cdots & t_{i m} / d_{i} \\
\vdots & & \vdots & & \vdots \\
t_{m 1} / d_{m} & \cdots & t_{m j} / d_{m} & \cdots & t_{m m} / d_{m}
\end{array}\right]_{m \times m}=\left[\begin{array}{ccccc}
t_{11}^{\alpha D} & \cdots & t_{1 j}^{\alpha D} & \cdots & t_{1 m}^{\alpha D} \\
\vdots & & \vdots & & \vdots \\
t_{i 1}^{\alpha D} & \cdots & t_{i j}^{\alpha D} & \cdots & t_{i m}^{\alpha D} \\
\vdots & & \vdots & & \vdots \\
t_{m 1}^{\alpha D} & \cdots & t_{m j}^{\alpha D} & \cdots & t_{m m}^{\alpha D}
\end{array}\right]_{m \times m}
$$


The normalized $\boldsymbol{T}_{D}^{\alpha}$ and the un-weighted super-matrix $\boldsymbol{W}$ (shown as Eq. (11)), and the weighted super-matrix $\boldsymbol{W}^{\alpha}$ (normalized super-matrix) can be easily obtained by Eq. (14), where $t_{i j}^{\alpha D}$ is a scalar and $\sum_{j=1}^{m} m_{j}=n$ :

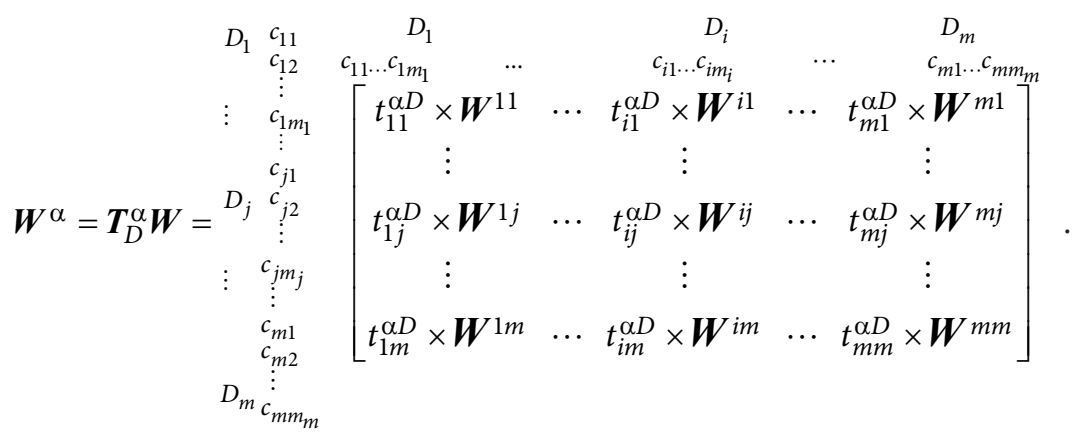

Step 7: Calculate the limit super-matrix $\boldsymbol{W}^{\alpha}$. Limit the weighted super-matrix by raising it to the $z$ th power, until the super-matrix has converged and become a stable super-matrix. The global priority vectors are obtained, which are called the influential weights of DANP (DEMATEL-based ANP), such as $\lim _{z \rightarrow \infty}\left(\boldsymbol{W}^{\alpha}\right)^{z}$, where $z$ represents any number of power.

In brief, according to the above process, the INRM and the influence weights of DANP can be obtained. Both the above (INRM and DANP) can be used to cope with the problem of interdependence and feedback in order to innovate/create the best systematic improvement strategies to reduce the gaps of criteria performance, in order that all criteria can achieve the aspiration level.

\subsection{Modified VIKOR method}

The VIKOR method, as developed by Opricovic and Tzeng (2004, 2007), solves MADM problems with conflicting criteria. This method is used as the basic concept of the TOPSIS method (Hwang, Yoon 1981) on Euclidean distances to the positive ideal (this research adopts the aspiration level) and the negative ideal (this research adopts the worst level) solutions, and TOPSIS used the class Euclidean distance function (Yu 1973), as based the concept of the positive ideal and negative ideal solutions; then Opricovic and Tzeng (2004) found that the TOPSIS method cannot be used in ranking or selection, and proposed the VIKOR method to replace the TOPSIS method, by comparing the preference distance of all real alternatives in order to stay close to the positive-ideal point; however, this research adopted the basic idea of the traditional thinking of the VIKOR method to replace staying close to the aspiration level (Liu et al. 2012; Chen 2015; Hu et al. 2015). The gap concept measures the proximity to the positive ideal point in order to modify the aspiration level point. In a different view-point, the relative good solution (ideal solution) from the existing alternatives (traditional VIKOR method) is replaced by the aspiration levels (modified VIKOR method), in order to support $\mathrm{DM}(\mathrm{s})$ to pursue excellence. The idea of aspiration levels was proposed by the Nobel Prize Laureate H. A. Simon (1955, 1956, and 1959), and replaced the classic selection or optimization decision based on Min-Max values by searching for the aspiration levels at each stage, 
and the decision process would be regarded as the pursuit of continuous improvements or enhancements. The modified VIKOR method is, as follows:

Step 1: Derive the positive-ideal solution and negative-ideal solution replaced by the aspiration levels and the worst value to fit today's real world situation. Define the best value (aspiration level) shown as $f_{j}^{\text {aspire }}$ in $j$ criterion and the worst value $f_{j}^{\text {worst }}$ for all criteria, which can be acquired from the traditional form to the modified form:

1) Traditional approach for deriving the positive-ideal solution and negative-ideal solution as follows:

The positive-ideal solution: $\boldsymbol{f}^{*}=\left(f_{1}^{*}, \ldots, f_{j}^{*}, \ldots, f_{n}^{*}\right)$, where $f_{j}^{*}=\max _{k}\left\{f_{k j} \mid k=1,2, \ldots, K\right\}$;

The negative-ideal solution: $\boldsymbol{f}^{-}=\left(f_{1}^{-}, \ldots, f_{j}^{-}, \ldots, f_{n}^{-}\right)$, where $f_{j}^{-}=\min _{k}\left\{f_{k j} \mid k=1,2, \ldots, K\right\}$.

2) The modified approach for replacement by the aspiration level and the worst value, as follows:

The aspiration level: $\boldsymbol{f}^{\text {aspire }}=\left(f_{1}^{\text {aspire }}, \ldots, f_{j}^{\text {aspire }}, \ldots, f_{n}^{\text {aspire }}\right)$, where $f_{j}^{\text {aspire }}$ is an aspiration level, or called the best value;

The worst values: $\boldsymbol{f}^{\text {worst }}=\left(f_{1}^{\text {worst }}, \ldots, f_{j}^{\text {worst }}, \ldots, f_{n}^{\text {worst }}\right)$, where $f_{j}^{\text {worst }}$ is a worst value.

In this study, the performance range-scores from 0 to 10 (very bad $\leftarrow 0,1,2, \ldots, 9,10 \rightarrow$ very good) are used with natural language in the linguistic/semantic questionnaire, thus, the aspiration level takes the highest score of 10 and the worst value takes the value of 0 . Hence, $f_{j}^{a s p i r e}=10$ is defined as the aspiration level and $f_{j}^{\text {worst }}=0$ as the worst value, it can avoid choosing the best among inferior choices/ options/alternatives. In other words, it avoids "picking the best apple from a barrel of rotten apples".

Step 2: Determine the mean group utility $S_{k}$ for the gap and maximal gap $Q_{k}$ for prioritizing improvement. These values can be calculated using Eqs. (15) and (16), respectively:

$$
\begin{gathered}
S_{k}=\sum_{j=1}^{n} w_{j} r_{k j}=\sum_{j=1}^{n} w_{j}\left(\left|f_{j}^{a s p i r e}-f_{k j}\right|\right) /\left(\left|f_{j}^{a s p i r e}-f_{j}^{\text {worst }}\right|\right) ; \\
Q_{k}=\max _{j}\left\{\left(\left|f_{j}^{\text {aspire }}-f_{k j}\right|\right) /\left(\left|f_{j}^{\text {aspire }}-f_{j}^{\text {worst }}\right|\right) \mid j=1,2, \ldots, n\right\},
\end{gathered}
$$

where $S_{k}$ is defined as the normalized ratio of distance to the aspiration level, which implies the synthesized gap for the criteria. On the other hand, $Q_{k}$ is defined as the normalized ratio of distance to the worst value, which implies the maximal gap in $j$ criteria for priority improvement. Here, $w_{j}$ indicates the influential weights for the criteria obtained from DANP, and $r_{k j}$ indicates the normalized gap of the distance to the aspiration level.

Step 3: Obtain the comprehensive indicator $R_{k}$ for ranking and selection in the traditional VIKOR approach. The values are given by:

$$
R_{k}=v\left(S_{k}-S^{*}\right) /\left(S^{-}-S^{*}\right)+(1-v)\left(Q_{k}-Q^{*}\right) /\left(Q^{-}-Q^{*}\right),
$$

where $S^{*}=\min _{k} S_{k}, S^{-}=\max _{k} S_{k}, Q^{*}=\min _{k} Q_{k}, \mathrm{Q}^{-}=\max _{k} \mathrm{Q}_{k}$ and $0 \leq v \leq 1$, where $v$ denotes the weight on the strategy of the maximum group utility, and $1-v$ is the weight on the individual regret (maximal gap for priority improvement). Therefore, Eq. (17) can be rewritten as $R_{k}=v S_{k}+(1-v) Q_{k}$ in the modified VIKOR to replace the traditional VIKOR approach, when $S^{*}=S^{\text {aspire }}=0$ and $Q^{*}=Q^{\text {aspire }}=0$ as well as $S^{-}=S^{\text {worst }}=1$ and $Q^{-}=Q^{\text {worst }}=1$ are set. If $v=1$ represents only the consideration of the average gap weighting integration, then 
$v=0$ can be regarded as the maximum gap regarding the improvement priority. Generally speaking, $v=0.5$ can be set, but can be adjusted depending on expert opinion in the value integration (because value measure is a non-additive situation in the real world).

All in all, the modified VIKOR can be used in the ranking and selection of alternatives, and for the improvement performance-gaps of criteria, as based on INRM by systematics, to avoid "stop-gap piecemeal" and avoids "picking the best apple from a barrel of rotten apples", and can even be used to solve any daily or single issue (i.e., only one issue, no other alternatives) for improvement performance-gap in considering all perspectives (dimensions), criteria, etc.

\section{An empirical case: an improvement plan for Guangzhou regional financial center modernization}

This Section mainly discusses the current status and issues facing Guangzhou regional financial center modernization development as an example to demonstrate the suitability of the proposed new hybrid MADM model for solving real world problems. The priorities for performance improvement are based on the results of the questionnaire survey and evaluation process. A diagram of the empirical case study is illustrated in Figure 2.

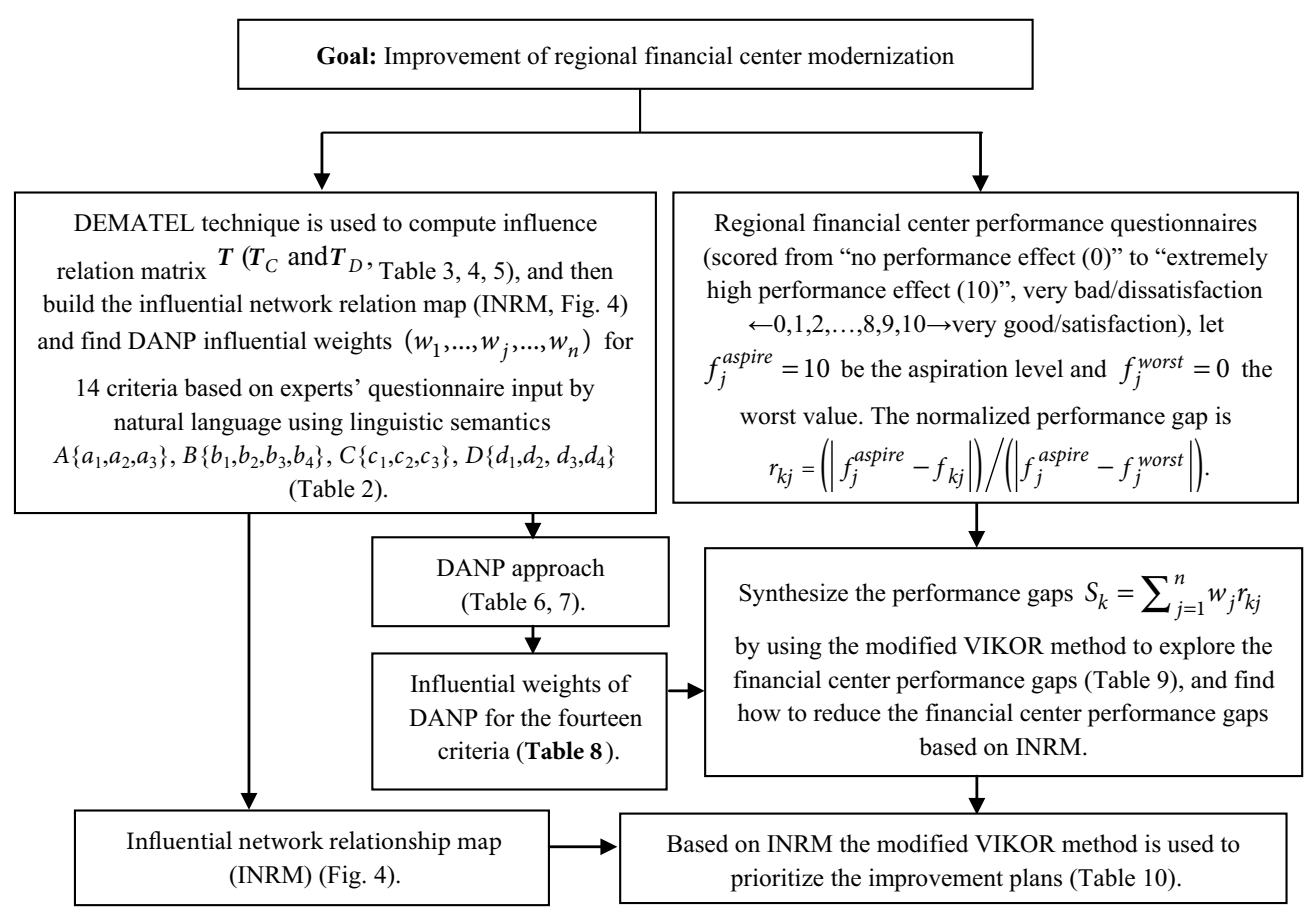

Fig. 2. Diagram of the process for the empirical case. 


\subsection{Background and problem statements}

In order to promote Guangdong economic development and enhance financial industry modernization, the Guangzhou government established and promoted the "Guangzhou Regional Financial Center Construction Plan (2011-2020)” in May 2011, in an attempt to build a financial hub with a wide range of radiation, financial industry cohesion, and highly efficient financial services, in order to achieve the target of regional economic leveraged growth. While Guangzhou has a robust financial infrastructure, its development is unbalanced, meaning that banking and insurance industries are in progress, stock market development is slow, the proportion of direct finance is low, financial innovation is insufficient, and high-level talents are lacking. Building a financial center in Guangzhou is required to further deepen China's financial system, particularly financial management, financial administrative reform and adjustment, and more openness in financial institutions and financial markets. Guangzhou is a national central city and a comprehensive gateway, which intensifies the need for regional financial center modernization to improve local and national economic development. A map of China's regional financial center is as shown in Figure 3.

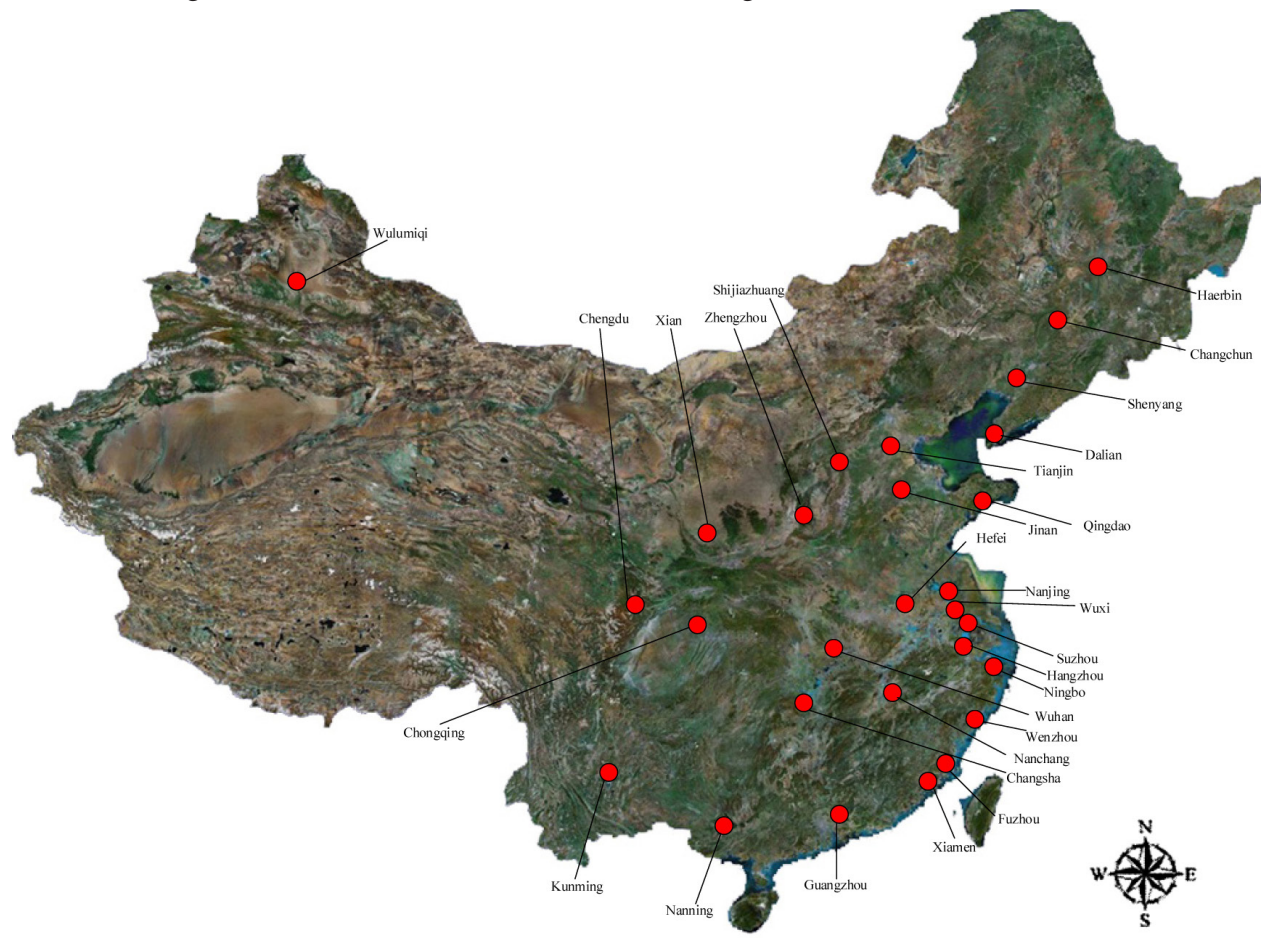

Fig. 3. China’s regional financial center map

\subsection{Operations and results}

This paper proposes a model for the improvement of regional financial center modernization in China, which can be expected to improve its service quality and efficiency. The network structure is constructed based on the DEMATEL technique, which demonstrates the networks 
of perspectives (dimensions) of regional financial center modernization. The average initial direct influence relation $4 \times 4$ matrix $\boldsymbol{B}$ is obtained through pair-wise comparisons to indicate the direction of the influences of dimensions on each other, and the normalized direct influence relation matrix $\boldsymbol{D}$ is measured using Eqs. (1) and (2). Then, the total influence matrix relation $T_{D}$ of the dimensions, the total influence relation of matrix $T_{C}$ of the criteria using Eqs. (3), (5), and (6), and the sum of the total influence given and received by each dimension and criterion can be shown, as in Tables 3 and 5. Significant confidence reached $98.8 \%$ in the results of the questionnaire survey by experts in practical experience (see "Note" of Table 4). These two total influence relation matrix $\boldsymbol{T}_{D}$ and $\boldsymbol{T}_{C}$ can measure the influences, given $d_{i}$ and received $r_{i}, d_{i}+r_{i}$ and $d_{i}-r_{i}$ for building the INRM to conduct the degree of relationship between the dimensions and the effect of one dimension on others, respectively; the total influence relation matrix of the criteria as shown in Table 4; a diagram of the INRM was constructed, as shown in Figure 4, which indicate that all perspectives are interdependent.

Table 3. Total influence relation matrix $\boldsymbol{T}_{D}$ : four perspectives (or called Dimensions)

\begin{tabular}{lcccccccc}
\hline Perspectives & $A$ & $B$ & $C$ & $D$ & $\begin{array}{c}\text { Row sum } \\
\left(d_{i}\right)\end{array}$ & $\begin{array}{c}\text { Column } \\
\text { sum }\left(r_{i}\right)\end{array}$ & $d_{i}+r_{i}$ & $d_{i}-r_{i}$ \\
\hline $\mathrm{A}$ & 0.418 & 0.463 & 0.479 & 0.427 & 1.787 & 1.543 & 3.329 & $0.244(1)$ \\
\hline $\mathrm{B}$ & 0.391 & 0.400 & 0.428 & 0.382 & 1.602 & 1.637 & 3.239 & $-0.035(2)$ \\
\hline $\mathrm{C}$ & 0.378 & 0.397 & 0.388 & 0.365 & 1.528 & 1.682 & 3.210 & $-0.154(4)$ \\
\hline $\mathrm{D}$ & 0.356 & 0.377 & 0.386 & 0.331 & 1.450 & 1.505 & 2.955 & $-0.055(3)$ \\
\hline
\end{tabular}

Table 4. Total influence relation matrix $\boldsymbol{T}_{C}$ : fourteen criteria

\begin{tabular}{ccccccccccccccc}
\hline 㞼 & & & & & & & & & & & & & & \\
岂 & $a_{1}$ & $a_{2}$ & $a_{3}$ & $b_{1}$ & $b_{2}$ & $b_{3}$ & $b_{4}$ & $c_{1}$ & $c_{2}$ & $c_{3}$ & $d_{1}$ & $d_{2}$ & $d_{3}$ & $d_{4}$ \\
\hline$a_{1}$ & 0.375 & 0.451 & 0.474 & 0.458 & 0.495 & 0.490 & 0.465 & 0.500 & 0.506 & 0.489 & 0.467 & 0.471 & 0.428 & 0.404 \\
\hline$a_{2}$ & 0.432 & 0.376 & 0.457 & 0.439 & 0.488 & 0.491 & 0.458 & 0.494 & 0.492 & 0.459 & 0.445 & 0.456 & 0.414 & 0.408 \\
\hline$a_{3}$ & 0.409 & 0.420 & 0.364 & 0.427 & 0.457 & 0.454 & 0.435 & 0.460 & 0.465 & 0.446 & 0.425 & 0.426 & 0.390 & 0.386 \\
\hline$b_{1}$ & 0.364 & 0.375 & 0.387 & 0.318 & 0.411 & 0.415 & 0.399 & 0.407 & 0.415 & 0.401 & 0.384 & 0.387 & 0.350 & 0.352 \\
\hline$b_{2}$ & 0.399 & 0.413 & 0.412 & 0.399 & 0.378 & 0.450 & 0.426 & 0.452 & 0.451 & 0.425 & 0.418 & 0.419 & 0.379 & 0.389 \\
\hline$b_{3}$ & 0.377 & 0.383 & 0.391 & 0.380 & 0.424 & 0.358 & 0.407 & 0.428 & 0.430 & 0.415 & 0.394 & 0.387 & 0.357 & 0.361 \\
\hline$b_{4}$ & 0.384 & 0.401 & 0.402 & 0.400 & 0.441 & 0.444 & 0.353 & 0.445 & 0.444 & 0.430 & 0.406 & 0.403 & 0.362 & 0.371 \\
\hline$c_{1}$ & 0.345 & 0.355 & 0.363 & 0.350 & 0.387 & 0.387 & 0.366 & 0.329 & 0.392 & 0.378 & 0.364 & 0.360 & 0.326 & 0.324 \\
\hline$c_{2}$ & 0.391 & 0.394 & 0.409 & 0.390 & 0.430 & 0.428 & 0.409 & 0.431 & 0.370 & 0.415 & 0.393 & 0.398 & 0.366 & 0.364 \\
\hline$c_{3}$ & 0.369 & 0.380 & 0.397 & 0.381 & 0.412 & 0.412 & 0.408 & 0.409 & 0.428 & 0.341 & 0.391 & 0.398 & 0.348 & 0.346 \\
\hline$d_{1}$ & 0.371 & 0.372 & 0.384 & 0.374 & 0.413 & 0.415 & 0.392 & 0.415 & 0.422 & 0.394 & 0.323 & 0.374 & 0.347 & 0.349 \\
\hline$d_{2}$ & 0.377 & 0.386 & 0.401 & 0.384 & 0.420 & 0.420 & 0.398 & 0.417 & 0.431 & 0.391 & 0.377 & 0.330 & 0.346 & 0.356 \\
\hline$d_{3}$ & 0.334 & 0.346 & 0.350 & 0.342 & 0.373 & 0.376 & 0.364 & 0.379 & 0.378 & 0.356 & 0.341 & 0.340 & 0.266 & 0.317 \\
\hline$d_{4}$ & 0.305 & 0.326 & 0.325 & 0.314 & 0.356 & 0.355 & 0.328 & 0.351 & 0.360 & 0.340 & 0.330 & 0.337 & 0.307 & 0.253 \\
\hline & & & & & & & & & & & \\
\hline
\end{tabular}

Note: Average difference in consensus gap-ratio $(\%)=\frac{1}{n^{2}} \sum_{i} \sum_{j}\left(\frac{\left|t_{i j}^{H}-t_{i j}^{H-1}\right|}{t_{i j}^{H}}\right) \times 100 \%=1.2 \%<5 \%$, i.e., significant confidence is $98.8 \%$, where $t_{i j}^{H-1}$ and $t_{i j}^{H}$ denote the average scores of the experts for number of $H-1=29$ and $H=30$ respectively; and $n$ denotes number of criteria, here $n=14$ and $14 \times 14$ matrix. 
An examination of Table 3 shows that the perspective of government policy $(A)$ is the factor that has the most influential strength given and received (3.329 of the total sum $d_{i}+r_{i}$ ), followed by financial infrastructure and safety $(B)$, financial service $(C)$, and financial institutions and human resources $(D)$, respectively. In other words, government policy $(A)$ is the most important influential perspective. Moreover, since the value of $d_{i}-r_{i}$ for $(A)$ dimension is positive, it means that this perspective affects the other perspectives, implying it should be
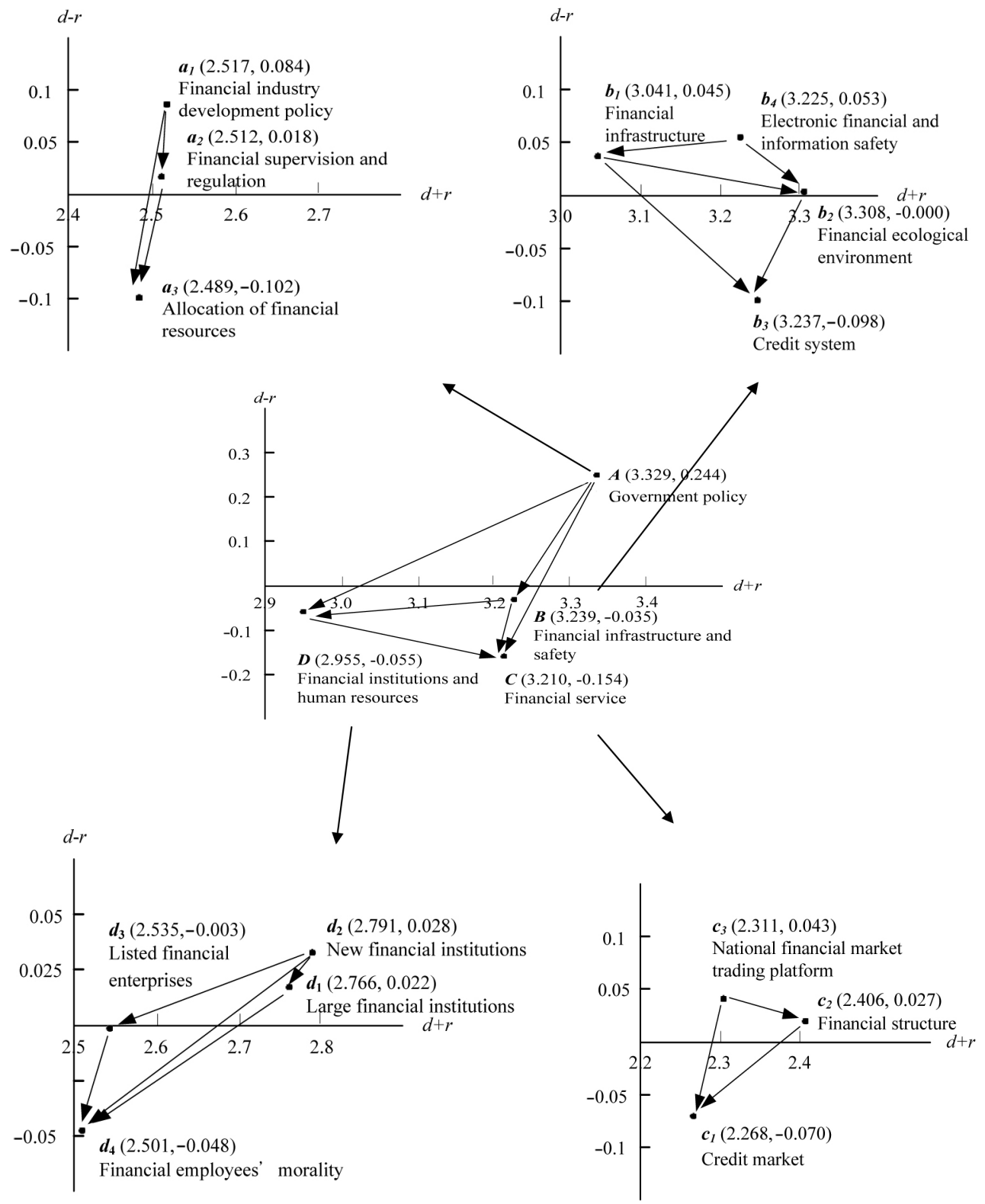

Fig. 4. The INRM of total influence relationships for the regional financial center modernization 
a top priority for improvement. It can be seen that government policy $(A)$ has the strongest degree of impact in a relationship that directly affects other dimensions, while financial service $(C)$ is the most sensitive to impact. In order to achieve greater quality regional financial center modernization in the light of Table 3, government policy $(A)$ is the first priority for improvement, as it can have an influential effect on the remaining dimensions. Therefore, the best strategy for improving regional financial center modernization is to improve government policy. The elements of the total influence matrix $\boldsymbol{T}$ are as listed in Table 4; which indicate that all criteria are interdependent (Group consensuses of 30 experts with the consensus value in average difference/gap only are $1.2 \%$ (less than $5 \%$ ), and the significance of the confidence level reaches $98.8 \%$ (more than $95 \%$, in "Note" of Table 4 ).

Table 5 shows the network of relationships influencing each criterion. The most important consideration $\left(d_{i}+r_{i}\right.$ is the highest $)$ is the financial ecological environment $\left(b_{2}\right)$ for the requirements of financial center modernization development. On the other hand, the credit market $\left(c_{1}\right)$ is the criteria with the least impact on the other criteria $\left(d_{i}+r_{i}\right.$ is the lowest) for financial center modernization. Financial industry development policy $\left(a_{1}\right)$ has the maximum value of all criteria, indicating that this criterion has the greatest direct impact on others $\left(d_{i}-r_{i}\right.$ is the highest); whereas, allocation of financial resources $\left(a_{3}\right)$ is the criterion most easily influenced by other criteria $\left(d_{i}-r_{i}\right.$ is the lowest).

Table 5. The sum of the influences given and received on the perspectives and criteria

\begin{tabular}{lllll}
\hline \multicolumn{1}{c}{ Perspectives/Criteria } & $\begin{array}{c}\text { Row sum } \\
\left(d_{i}\right)\end{array}$ & $\begin{array}{c}\text { Column } \\
\text { sum }\left(r_{i}\right)\end{array}$ & $d_{i}+r_{i}$ & $d_{i}-r_{i}$ \\
\hline Government policy $(A)$ & 1.787 & 1.543 & 3.329 & 0.244 \\
\hline Financial industry development policy $\left(a_{1}\right)$ & 1.301 & 1.216 & 2.517 & 0.084 \\
\hline Financial supervision and regulation $\left(a_{2}\right)$ & 1.265 & 1.247 & 2.512 & 0.018 \\
\hline Allocation of financial resources $\left(a_{3}\right)$ & 1.193 & 1.296 & 2.489 & -0.102 \\
\hline Financial infrastructure and safety $(B)$ & 1.602 & 1.637 & 3.239 & -0.035 \\
\hline Financial infrastructure $\left(b_{1}\right)$ & 1.543 & 1.498 & 3.041 & 0.045 \\
\hline Financial ecological environment $\left(b_{2}\right)$ & 1.654 & 1.654 & 3.308 & -0.000 \\
\hline Credit systems $\left(b_{3}\right)$ & 1.569 & 1.668 & 3.237 & -0.098 \\
\hline Electronic financial and information safety $\left(b_{4}\right)$ & 1.639 & 1.586 & 3.225 & 0.053 \\
\hline Financial service $(C)$ & 1.528 & 1.682 & 3.210 & -0.154 \\
\hline Credit market $\left(c_{1}\right)$ & 1.099 & 1.169 & 2.268 & -0.070 \\
\hline Financial structure $\left(c_{2}\right)$ & 1.217 & 1.189 & 2.406 & 0.027 \\
\hline National financial market trading platform $\left(c_{3}\right)$ & 1.177 & 1.134 & 2.311 & 0.043 \\
\hline Financial institutions and human resources $(D)$ & 1.450 & 1.505 & 2.955 & -0.055 \\
\hline Large financial institutions $\left(d_{1}\right)$ & 1.394 & 1.372 & 2.766 & 0.022 \\
\hline New financial institutions $\left(d_{2}\right)$ & 1.410 & 1.381 & 2.791 & 0.028 \\
\hline Listed financial enterprises $\left(d_{3}\right)$ & 1.266 & 1.269 & 2.535 & -0.003 \\
\hline Financial employees' morality $\left(d_{4}\right)$ & 1.227 & 1.275 & 2.501 & -0.048 \\
\hline & & & & \\
\hline
\end{tabular}


A significant causal relationship can be observed among the four perspectives. The values of $d_{i}-r_{i}$ for $A$ (government policy) are positive, meaning that this perspective affects other perspectives. On the other hand, the values of $d_{i}-r_{i}$ for perspective $B$ (financial infrastructure and safety), perspective $C$ (financial service), and perspective $D$ (financial institutions and human resources) are negative, implying that these perspectives are influenced by another perspectives (government policy). Based on these findings, decision-makers can easily identify priorities for improvement from among complex criteria.

The data computed from the second stage through DEMATEL was combined with DANP, and the dynamic relationship was obtained among the criteria. However, in order to find the weight of each criterion, the regional financial center modernization model must be structured using DANP. The DEMATEL-based un-weighted super-matrix is obtained by using the Eqs. (10), (11), and (12), as shown in Table 6. The weighted super-matrix (Table 7) is calculated from Eqs. (8), (14), and (15) to reflect the degrees of influence exerted by the various dimensions. The limiting power of the weighted super-matrix is used to form a long-term stable condition, and represents the weights of various criteria (global weights), as listed in Table 8. This result, obtained via the DANP method, is applied to the modified VIKOR method by determining each criterion performance score.

Table 6. Un-weighted super-matrix $\boldsymbol{W}$ based on DANP for financial center modernization elements

\begin{tabular}{|c|c|c|c|c|c|c|c|c|c|c|c|c|c|c|}
\hline Uี & $a_{1}$ & $a_{2}$ & $a_{3}$ & $b_{1}$ & $b_{2}$ & $b_{3}$ & $b_{4}$ & $c_{1}$ & $c_{2}$ & $c_{3}$ & $d_{1}$ & $d_{2}$ & $d_{3}$ & $d_{4}$ \\
\hline$a_{1}$ & 0.289 & 0.341 & 0.343 & 0.323 & 0.326 & 0.327 & 0.324 & 0.324 & 0.328 & 0.322 & 0.329 & 0.324 & 0.324 & 0.319 \\
\hline$a_{2}$ & 0.347 & 0.297 & 0.352 & 0.333 & 0.338 & 0.333 & 0.338 & 0.334 & 0.330 & 0.332 & 0.330 & 0.332 & 0.336 & 0.341 \\
\hline$a_{3}$ & 0.364 & 0.362 & 0.305 & 0.344 & 0.337 & 0.340 & 0.339 & 0.341 & 0.342 & 0.346 & 0.341 & 0.344 & 0.340 & 0.339 \\
\hline$b_{1}$ & 0.240 & 0.234 & 0.241 & 0.206 & 0.241 & 0.242 & 0.244 & 0.235 & 0.235 & 0.236 & 0.235 & 0.236 & 0.235 & 0.232 \\
\hline$b_{2}$ & 0.260 & 0.260 & 0.258 & 0.266 & 0.229 & 0.270 & 0.269 & 0.260 & 0.259 & 0.255 & 0.259 & 0.259 & 0.256 & 0.263 \\
\hline$b_{3}$ & 0.257 & 0.262 & 0.256 & 0.269 & 0.272 & 0.228 & 0.271 & 0.259 & 0.258 & 0.256 & 0.260 & 0.259 & 0.258 & 0.263 \\
\hline$b_{4}$ & .244 & 0.244 & 0.245 & 0.259 & 0.258 & 0.259 & 0.215 & 0.245 & 0.247 & 0.253 & 0.246 & 0.246 & 0.250 & 0.243 \\
\hline$c_{1}$ & 0.334 & 0.342 & 0.336 & 0.333 & 0.340 & 0.341 & 0.337 & 0.300 & 0.354 & 0.347 & 0.337 & 0.337 & 0.340 & 0.334 \\
\hline$c_{2}$ & 0.338 & 0.341 & 0.339 & 0.339 & 0.340 & 0.338 & 0.337 & 0.356 & 0.304 & 0.363 & 0.343 & 0.348 & 0.340 & 0.342 \\
\hline$c_{3}$ & 0.327 & 0.317 & 0.325 & 0.328 & 0.320 & 0.321 & 0.326 & 0.344 & 0.341 & 0.289 & 0.320 & 0.315 & 0.320 & 0.324 \\
\hline$d_{1}$ & 0.264 & 0.258 & 0.261 & 0.261 & 0.261 & 0.263 & 0.263 & 0.265 & 0.258 & 0.264 & 0.232 & 0.268 & 0.269 & 0.269 \\
\hline$d_{2}$ & 0.266 & 0.265 & 0.262 & 0.263 & 0.261 & 0.258 & 0.261 & 0.262 & 0.262 & 0.268 & 0.268 & 0.234 & 0.268 & 0.275 \\
\hline$d_{3}$ & 0.242 & 0.240 & 0.240 & 0.237 & 0.236 & 0.238 & 0.235 & 0.237 & 0.241 & 0.234 & 0.249 & 0.246 & 0.212 & 0.250 \\
\hline$d_{4}$ & 0.228 & 0.237 & 0.237 & 0.239 & 0.242 & 0.241 & 0.240 & 0.236 & 0.239 & 0.233 & 0.251 & 0.252 & 0.250 & 0.206 \\
\hline
\end{tabular}


Table 7. Weighted super-matrix $\boldsymbol{W}^{\alpha}$ based on DANP for financial center modernization elements

\begin{tabular}{ccccccccccccccc}
\hline 离 & & & & & & & & & & & & & & \\
莺 & $a_{1}$ & $a_{2}$ & $a_{3}$ & $b_{1}$ & $b_{2}$ & $b_{3}$ & $b_{4}$ & $c_{1}$ & $c_{2}$ & $c_{3}$ & $d_{1}$ & $d_{2}$ & $d_{3}$ & $d_{4}$ \\
\hline$a_{1}$ & 0.058 & 0.068 & 0.069 & 0.068 & 0.068 & 0.069 & 0.068 & 0.069 & 0.070 & 0.068 & 0.070 & 0.069 & 0.069 & 0.067 \\
\hline$a_{2}$ & 0.070 & 0.060 & 0.071 & 0.070 & 0.071 & 0.070 & 0.071 & 0.071 & 0.070 & 0.070 & 0.070 & 0.070 & 0.071 & 0.072 \\
\hline$a_{3}$ & 0.073 & 0.073 & 0.061 & 0.072 & 0.071 & 0.071 & 0.071 & 0.072 & 0.073 & 0.074 & 0.072 & 0.073 & 0.072 & 0.072 \\
\hline$b_{1}$ & 0.071 & 0.069 & 0.071 & 0.059 & 0.069 & 0.069 & 0.070 & 0.070 & 0.070 & 0.070 & 0.070 & 0.070 & 0.070 & 0.069 \\
\hline$b_{2}$ & 0.077 & 0.077 & 0.076 & 0.076 & 0.066 & 0.077 & 0.077 & 0.077 & 0.077 & 0.076 & 0.077 & 0.077 & 0.076 & 0.078 \\
\hline$b_{3}$ & 0.076 & 0.078 & 0.076 & 0.077 & 0.078 & 0.065 & 0.078 & 0.077 & 0.077 & 0.076 & 0.078 & 0.077 & 0.077 & 0.078 \\
\hline$b_{4}$ & 0.072 & 0.072 & 0.073 & 0.074 & 0.074 & 0.074 & 0.062 & 0.073 & 0.073 & 0.075 & 0.073 & 0.073 & 0.078 & 0.072 \\
\hline$c_{1}$ & 0.077 & 0.079 & 0.077 & 0.077 & 0.078 & 0.077 & 0.078 & 0.065 & 0.077 & 0.076 & 0.077 & 0.077 & 0.078 & 0.077 \\
\hline$c_{2}$ & 0.078 & 0.078 & 0.078 & 0.078 & 0.078 & 0.078 & 0.077 & 0.078 & 0.066 & 0.079 & 0.079 & 0.080 & 0.073 & 0.078 \\
\hline$c_{3}$ & 0.075 & 0.073 & 0.075 & 0.075 & 0.074 & 0.075 & 0.075 & 0.075 & 0.074 & 0.063 & 0.073 & 0.072 & 0.072 & 0.074 \\
\hline$d_{1}$ & 0.072 & 0.071 & 0.071 & 0.071 & 0.071 & 0.072 & 0.072 & 0.072 & 0.070 & 0.072 & 0.061 & 0.070 & 0.071 & 0.071 \\
\hline$d_{2}$ & 0.073 & 0.072 & 0.071 & 0.072 & 0.071 & 0.071 & 0.071 & 0.072 & 0.071 & 0.073 & 0.070 & 0.061 & 0.070 & 0.072 \\
\hline$d_{3}$ & 0.066 & 0.066 & 0.066 & 0.065 & 0.065 & 0.065 & 0.064 & 0.065 & 0.066 & 0.064 & 0.065 & 0.064 & 0.056 & 0.065 \\
\hline$d_{4}$ & 0.062 & 0.065 & 0.065 & 0.065 & 0.066 & 0.066 & 0.066 & 0.064 & 0.065 & 0.064 & 0.066 & 0.066 & 0.065 & 0.054 \\
\hline
\end{tabular}

Table 8. Influential weights of DANP for each criterion obtained by $\lim _{z \rightarrow \infty}\left(\boldsymbol{W}^{\alpha}\right)^{z}$

\begin{tabular}{ccccccccccccccc}
\hline Criteria & $a_{1}$ & $a_{2}$ & $a_{3}$ & $b_{1}$ & $b_{2}$ & $b_{3}$ & $b_{4}$ & $c_{1}$ & $c_{2}$ & $c_{3}$ & $d_{1}$ & $d_{2}$ & $d_{3}$ & $d_{4}$ \\
\hline $\begin{array}{l}\text { Weights } \\
\text { (DANP) }\end{array}$ & 0.068 & 0.070 & 0.071 & 0.069 & 0.076 & 0.076 & 0.073 & 0.076 & 0.077 & 0.073 & 0.071 & 0.071 & 0.065 & 0.064 \\
\hline
\end{tabular}

The modified VIKOR method is employed to evaluate the overall performance gaps (or so-called regret) of regional financial center modernization. The score of each criterion and the total average gap $\left(S_{k}=\sum_{j=1}^{n} w_{j} r_{k j}\right)$ in China's regional financial center modernization are acquired by taking the global weights from the DANP influential weights in order to multiply the gap $\left(r_{k j}\right)$. The average performance value can be obtained from the performance values $\left(f_{k j} \mid j=1,2, \ldots, n\right)$ and relative gaps $\left(r_{k j}=\left|f_{j}^{a s p i r e}-f_{k j}\right| /\left|f_{j}^{a s p i r e}-f_{j}^{\text {worst }}\right| \mid j=1,2, \ldots, n\right)$ of all criteria, as illustrated in Table 9. With the help of these performance values, decision-makers are able to find solutions for all types of problems for each perspective, or the perspective of the criteria as a whole. The government policy $(A)$ has the highest performance value of 7.218, as compared with the other dimensions. On the other hand, financial institutions and human resources $(D)$ have the lowest performance value of 6.91, as compared with the other dimensions. It can be seen that the total average performance is 7.079; whereas, the total average gap from the aspired value is 0.292 , indicating that the distance from the optimal level exceeds $29.2 \%$. 
Table 9. Integrated index of financial center modernization dimensions and criteria

\begin{tabular}{lllll}
\hline & $\begin{array}{c}\text { Local } \\
\text { weights }\end{array}$ & $\begin{array}{c}\text { Global } \\
\text { weights }\end{array}$ & Performance & $\begin{array}{c}\text { Relative } \\
\text { gaps }\end{array}$ \\
\hline Government policy $(A)$ & 0.209 & & $7.218(1)$ & $0.278(4)$ \\
\hline Financial industry development policy $\left(a_{1}\right)$ & 0.325 & 0.068 & 7.833 & 0.217 \\
\hline Financial supervision and regulation $\left(a_{2}\right)$ & 0.333 & 0.070 & 6.444 & 0.356 \\
\hline Allocation of financial resources $\left(a_{3}\right)$ & 0.342 & 0.071 & 7.389 & 0.261 \\
\hline Financial infrastructure and safety $(B)$ & 0.294 & & $7.103(3)$ & $0.290(2)$ \\
\hline Financial infrastructure $\left(b_{1}\right)$ & 0.235 & 0.069 & 6.944 & 0.306 \\
\hline Financial ecological environment $\left(b_{2}\right)$ & 0.259 & 0.076 & 7.556 & 0.244 \\
\hline Credit systems $\left(b_{3}\right)$ & 0.259 & 0.076 & 7.000 & 0.300 \\
\hline Electronic financial and information safety $\left(b_{4}\right)$ & 0.247 & 0.073 & 6.889 & 0.311 \\
\hline Financial service $(C)$ & 0.227 & & $7.122(2)$ & $0.288(3)$ \\
\hline Credit market $\left(c_{1}\right)$ & 0.337 & 0.076 & 6.611 & 0.339 \\
\hline Financial structure $\left(c_{2}\right)$ & 0.341 & 0.077 & 7.111 & 0.289 \\
\hline National financial market trading platform $\left(c_{3}\right)$ & 0.322 & 0.073 & 7.667 & 0.233 \\
\hline Financial institutions and human resources $(\boldsymbol{D})$ & 0.270 & & $6.910(4)$ & $0.309(1)$ \\
\hline Large financial institutions $\left(d_{1}\right)$ & 0.261 & 0.071 & 6.167 & 0.383 \\
\hline New financial institutions $\left(d_{2}\right)$ & 0.262 & 0.071 & 6.778 & 0.322 \\
\hline Listed financial enterprises $\left(d_{3}\right)$ & 0.239 & 0.065 & 7.333 & 0.267 \\
\hline Financial employees morality $\left(d_{4}\right)$ & 0.238 & 0.064 & 7.444 & 0.256 \\
\hline Total average performance & - & - & 7.079 & - \\
\hline Total average gap & - & - & - & $\mathbf{0 . 2 9 2}$ \\
\hline & & & & \\
\hline
\end{tabular}

\subsection{Discussion}

Figure 1 shows the causal relationship of the perspectives and criteria, as measured in this study, for the promotion of China's regional financial center modernization, as illustrated by systematics of INRM. Based on the degree of the dimension effect, improvements should be made according to the following order: government policy $(A)$, financial infrastructure and safety $(B)$, financial institutions and human resources $(D)$, and financial service $(C)$. The results indicate that government policy has the greatest immediate network effects on the other perspectives, and can help resolve multiple problems simultaneously. The findings imply that government policy on regional financial center modernization should be deepened for China, and the quality and effectiveness of service can be improved as a result. The main regular environment of a regional financial center should provide participants with a relative financial incentive system, and efficiently implement it. In order to enhance the financial market's operational efficiency and promote regional economy growth, the optimization financial policy is the best means to accomplish regional financial center modernization.

Within an individual dimension, the influences of network relationships of certain criteria also have the same effects; namely the financial industry development policy $\left(a_{1}\right)$, electronic financial and information safety $\left(b_{4}\right)$, national financial market trading platform $\left(c_{3}\right)$, and new financial institutions $\left(d_{2}\right)$. These are the major influential factors within each dimension, im- 
plying that they have priority in improvements, and provide a higher level model for regional financial center modernization. In terms of the result in the dimension of government policy (A); it suggests that government should promote a financial incentive system or a tax abatement program to strengthen regional financial center modernization development. This finding is similar to Deng et al. (2012), meaning tax incentives not only attract FDI, but also improve domestic firms' performance, which is conducive to regional economic development. In terms of the result in the dimension of financial infrastructure and safety $(B)$, we understand that enhancing electronic financial transaction information security is important for decision makers to manage financial infrastructure and safety. The dimension of financial service $(C)$ implies that the trade center of financial assets and foreign exchange market have to be set up first. Furthermore, in the financial institutions and human resources $(D)$ aspect, this finding showed that building a variety of new financial institutions is the most effective method for advancing regional financial center modernization. The details, from the perspectives of individual or overall point of view, of the framework for sustainable development are as shown in Table 10.

In addition, the overall performance value is 7.079 , as shown in Table 9, with 10 as the aspiration level. The total average gap indicating room for improvement is 0.392 . Table 9 also shows the performance value between each dimension/criterion and the gap value from the aspired level, and the descending rank of each dimension's performance is, as follows: $A_{-} C_{-} B_{-} D$. It is notable that financial institutions and human resources $(D)$ (gap value is 0.309 ) are the least confident dimensions, implying an acute shortage of financial institutions and human resources. Among the 15 criteria (Table 6), the "large financial institutions $\left(d_{1}\right)$ )" for China's regional financial center modernization development has the largest gap value. This shows that "large financial institutions $\left(d_{1}\right)$ " has the greatest room for improvement, implying that is the most unsatisfying and unachievable criterion, and must be increased. This information gives decision-makers a reference in planning for the enhancement of performance and comprehensive regional financial center modernization development. Administrative authority can better comprehend the current strengths and weakness through this information before launching a priority improvement strategy.

Table 10. The financial center modernization implementation improvement plan

\begin{tabular}{|c|c|}
\hline Items & $\begin{array}{c}\text { Strategy (Sequence of improvement } \\
\text { priority) }\end{array}$ \\
\hline F1: Influential network of dimensions of DEMATEL & $A_{-} B_{-} D_{-} C$ \\
\hline $\begin{array}{l}\text { F2: Influential network of criteria within individual } \\
\text { dimensions }\end{array}$ & $\begin{array}{l}A:\left(a_{1}\right)_{-}\left(a_{2}\right)_{-}\left(a_{3}\right) \\
\left(a_{2}\right)_{-}\left(a_{3}\right) \\
B:\left(b_{4}\right)_{-}\left(b_{1}\right)_{-}\left(b_{2}\right)_{-}\left(b_{3}\right) \\
\left(b_{1}\right)_{-}\left(b_{2}\right)_{-}\left(b_{3}\right) \\
\left(b_{2}\right)_{-}\left(b_{3}\right) \\
D:\left(d_{2}\right)_{-}\left(d_{1}\right)_{-}\left(d_{3}\right)_{-}\left(d_{4}\right) \\
\left(d_{1}\right)_{-}\left(d_{3}\right)_{-}\left(d_{4}\right) \\
\left(d_{3}\right)_{-}\left(d_{4}\right) \\
C:\left(c_{3}\right)_{-}\left(c_{2}\right)_{-}\left(c_{1}\right) \\
\left(c_{2}\right)_{-}\left(c_{1}\right)\end{array}$ \\
\hline
\end{tabular}




\section{Conclusions}

This research proposes an improvement strategy for Guangzhou regional financial center modernization, which may serve as reference for the government to evaluate the development of modernization. A new decision model is constructed by integrating DEMATEL, DANP, and modified VIKOR methods, to illustrate the inter-relationship between the influential factors. Here, DEMATEL is mainly used to construct the INRM and weighted super matrix, DANP is used to resolve the inter-dependency and feedback relationship, and the modified VIKOR method is employed to integrate the performance gaps of each criterion within each dimension and overall. Based on the degree of the effect and impact, consideration should be given, as follows: government policy, financial infrastructure and safety, financial institutions and human resources, and financial service. Among the fourteen criteria, the financial industry development policy is critical, and most likely to influence the other rules, and thus, is the first priority for improvement. A sequence is made on the basis of dimension performance in descending order, as follows: government policy, financial service, financial infrastructure and safety, and financial institutions and human resources. According to this finding, financial institutions and human resources have the biggest gap from the aspired/ desired level. The implications of these results for management and improvement strategies are illustrated in Table 10. In short, this study not only selected an appropriate regional financial center modernization development strategy, but also determined how to improve the gaps to achieve the aspired levels of determinants to enhance future performance.

The regional financial centers are set for more than 20 cities in China, thus, competition is intense. Local governments can promote their competitiveness by improving their modernization facilities, and enhancing their operational efficiency and quality through the results herein. The research methodology discussed herein is capable of dealing with complex issues related to the development of regional financial center modernization. Not only does this research have profound implications for responsible authorities, but even more important, it proposes a feasible and adequate development strategy for regional financial center modernization, which can assist the government in its shortcomings regarding improvements to the development of modernization.

Although this paper establishes a new model to evaluate regional financial center modernization effectiveness, some interesting points may be worth investigating in future research studies. The modified VIKOR in assessment to integrates each criterion into each dimension, and becomes a "non-additive type" (or "super-additive type") in the real world situation. However, this study still used the additive type in integrating each criterion into each dimension, and the "fuzzy integral" was used to solve "non-additive type" problem that integrates each criterion into each dimension. Thus, this better suits practical problems. The evaluation criteria were selected from a review of the literature on financial center modernization. However, the cloud computing industry is booming in recent years that has resulted in changes of the financial environment, and the relevant factors that may affect the development of the regional financial center modernization. Perhaps they may be important influential factors that should be considered in evaluating the impact of financial center modernization in future studies. Other methodologies can be used to identify other possible criteria, such as longitudinal studies. The number of expert samples can be increased in order to enhance the reliability of the results. 


\section{References}

Agostino, M.; Gagliardi, F.; Trivieri, F. 2010. Credit market structure and bank screening: an indirect test on Italian data, Review of Financial Economics 19(4): 151-160. https://doi.org/10.1016/j.rfe.2010.06.003

Allen, F.; Gu, X.; Kowalewski, O. 2012. Financial crisis, structure and reform, Journal of Banking \& Finance 36(11): 2960-2973. https://doi.org/10.1016/j.jbankfin.2012.06.002

Al-Salem, F.; Mohammed, M. 2012. Factors affecting the investment climate for an international financial center in Kuwait, The Journal of Applied Business Research 28(6): 1373-1384. https://doi.org/10.19030/ jabr.v28i6.7350

Amable, B.; Chatelain, J. B. 2001. Can financial infrastructures foster economic development?, Journal of Development Economics 64(2): 481-498. https://doi.org/10.1016/S0304-3878(00)00147-4

An, Z.; Li, D.; Yu, J. 2015. Firm crash risk, information environment, and speed of leverage adjustment, Journal of Corporate Finance 31: 132-151. https://doi.org/10.1016/j.jcorpfin.2015.01.015

Balan, D. J.; Knack, S. 2012. The correlation between human capital and morality and its effect on economic performance: theory and evidence, Journal of Comparative Economics 40: 457-475. https://doi.org/10.1016/j.jce.2011.12.005

Barth, J. R.; Lin, C.; Ma, Y.; Seade, J.; Song, F. M. 2013. Do bank regulation, supervision and monitoring enhance or impede bank efficiency?, Journal of Banking \& Finance 37(8): 2879-2892. https://doi.org/10.1016/j.jbankfin.2013.04.030

Baum, C. F.; Schäfer, D.; Talavera, O. 2011. The impact of the financial system's structure on firms' financial constraints, Journal of International Money and Finance 30(4): 678-691. https://doi.org/10.1016/j. jimonfin.2011.02.004

Bekaert, G.; Harvey, C. R.; Lundbla, C. 2005. Does financial liberalization spur growth?, Journal of Financial Economics 77(1): 3-55. https://doi.org/10.1016/j.jfineco.2004.05.007

Bena, J.; Ondko, P. 2012. Financial development and the allocation of external finance, Journal of Empirical Finance 19(1): 1-25. https://doi.org/10.1016/j.jempfin.2011.11.002

Boehne, E. G. 2000. Financial modernization: vastly different or fundamentally the same?, Business Review July/August: 3-14.

Bolbol, A. A.; Fatheldin, A.; Omran, M. M. 2005. Financial development, structure, and economic growth: the case of Egypt, 1974-2002, Research in International Business and Finance 19(1): 171-194. https://doi.org/10.1016/j.ribaf.2004.10.008

Brown, M.; Zehnder, C. 2010. The emergence of information sharing in credit markets, Journal of Financial Intermediation 19(2): 255-278. https://doi.org/10.1016/j.jfi.2009.03.001

Buck, F.; Schliephake, E. 2013. The regulator's trade-off: Bank supervision vs. minimum capital, Journal of Banking \& Finance 37(11): 4584-4598. https://doi.org/10.1016/j.jbankfin.2013.04.012

Cavalcanti, M. A. F. H. 2010. Credit market imperfections and the power of the financial accelerator: a theoretical and empirical investigation, Journal of Macroeconomics 32(1): 118-144. https://doi.org/10.1016/j.jmacro.2009.10.005

Cetorelli, N.; Peristiani, S. 2013. Prestigious stock exchanges: a network analysis of international financial centers, Journal of Banking \& Finance 37(5): 1543-1551. https://doi.org/10.1016/j.jbankfin.2012.06.011

Chen, F. S. 2015. Application of a hybrid dynamic MCDM to explore the key factors for the internal control of procurement circulation, International Journal of Production Research 53(10): 2951-2969. https://doi.org/10.1080/00207543.2014.961210

Chen, F. S.; Chi, D. J. 2015. Application of a new DEMATEL to explore key factors of China's corporate social responsibility: evidence from accounting experts, Quality and Quantity 49(1): 135-154. https://doi.org/10.1007/s11135-013-9978-2 
Chen, F. S.; Tzeng, G. H. 2015. Probing organization performance using a new hybrid dynamic MCDM method based on the balanced scorecard approach, Journal of Testing and Evaluation 43(4): 1-14. https://doi.org/10.1520/JTE20130181

Cobb, S. C. 1998. Global finance and the growth of offshore centers: the Manx experience, Geoforum 29(1): 7-21. https://doi.org/10.1016/S0016-7185(97)00022-5

De Hoogh, A. H. B.; Den Hartog, D. N. 2008. Ethical and despotic leadership, relationships with leader's social responsibility, top management team effectiveness and subordinates' optimism: a multi-method study, The Leadership Quarterly 19: 297-311. https://doi.org/10.1016/j.leaqua.2008.03.002

De las Mercedes Adamuz, M.; Cortés, J. H. 2015. Endogenous screening and the formation of loan syndicates, International Review of Economics and Finance 37: 290-307. https://doi.org/10.1016/j.iref.2014.12.002

Demirgüç-Kunt, A.; Laeven, L.; Levine, R. 2003. Regulations, market structure, institutions, and the cost of financial intermediation [online], [cited 13 September 2014]. NBER Working Paper No. 9890. Available from Internet: https://www.nber.org/papers/w9890

Deng, Z.; Falvey, R.; Blake, A. 2012. Trading market access for technology? Tax incentives, foreign direct investment and productivity spillovers in China, Journal of Policy Modelling 34(5): 675-690. https://doi.org/10.1016/j.jpolmod.2012.01.003

Doh, S.; Kim, B. 2014. Government support for SME innovations in the regional industries: the case of government financial support program in South Korea, Research Policy 43(9): 1557-1569. https://doi.org/10.1016/j.respol.2014.05.001

Farooq, O; El Ouadrhiri, K. 2014. Financial centers and firm performance during the crisis period: evidence from India, International Journal of Disclosure and Governance 11(2): 114-127. https://doi.org/10.1057/jdg.2012.17

Fase, M. M. G.; Abma, R. C. N. 2003. Financial environment and economic growth in selected Asian countries, Journal of Asian Economics 14(1): 11-21. https://doi.org/10.1016/S1049-0078(02)00237-3

Felix, R. A.; Hines Jr., J. R. 2013. Who offers tax-based business development incentives?, Journal of Urban Economics 75: 80-91. https://doi.org/10.1016/j.jue.2012.12.003

Fontela, E.; Gabus, A. 1976. The DEMATEL Observer. Battelle Institute, Geneva Research Center, Carouge, Switzerland.

Fu, S.; Xiao, Y. 2011. An effective process of information security risk assessment, Energy Procedia 11: 1050-1057.

Gao, T.; Gupta, A.; Gulpinar, N.; Zhu, Y. 2015. Optimal hedging strategy for risk management on a network, Journal of Financial Stability 16: 31-44. https://doi.org/10.1016/j.jfs.2014.10.005

Gertler, M.; Kiyotaki, N.; Queralto, A. 2012. Financial crises, bank risk exposure and government financial policy, Journal of Monetary Economics 59(Supplement): S17-S34. https://doi.org/10.1016/j.jmoneco.2012.11.007

Giannetti, C.; Jentzsch, N. 2013. Credit reporting, financial intermediation and identification systems: international evidence, Journal of International Money and Finance 33: 60-80. https://doi.org/10.1016/j.jimonfin.2012.10.005

Giannetti, M.; Laeven, L. 2012. The flight home effect: evidence from the syndicated loan market during financial crises, Journal of Financial Economics 104(1): 23-43. https://doi.org/10.1016/j.jineco.2011.12.006

Guan, J. C.; Yam, R. C. M. 2015. Effects of government financial incentives on firms' innovation performance in China: evidences from Beijing in the 1990s, Research Policy 44(1): 273-282. https://doi.org/10.1016/j.respol.2014.09.001 
Haselmann, R.; Wachtel, P. 2011. Foreign banks in syndicated loan markets, Journal of Banking \& Finance 35(10): 2679-2689. https://doi.org/10.1016/j.jbankfin.2011.02.023

Hoening, T. M. 1998. Financial modernization: implications for the safety net, Mercer Law Review 49: 787-791.

Hu, K. H.; Chen, F. H.; Tzeng, G. H.; Lee, J. D. 2015. Improving corporate governance effects on an enterprise crisis based on a new hybrid DEMATEL with the MADM model, Journal of Testing and Evaluation 43(6): 1394-1412. https://doi.org/10.1520/JTE20140094

Hwang, C. L.; Yoon, K. 1981. Multiple attribute decision making: a state-of-the art survey. Springer-Verlag, Berlin, Heidelberg, New York. https://doi.org/10.1007/978-3-642-48318-9

Jarvis, D. S. L. 2011. Race for the money: international financial centres in Asia, Journal of International Relations and Development 14: 60-95. https://doi.org/10.1057/jird.2010.19

Jirasek, V. 2012. Practical application of information security models, Information Security Technical Report 17(1-2): 1-8. https://doi.org/10.1016/j.istr.2011.12.004

Kankanhalli, A.; Teo, H. H.; Tan, B. C. Y.; Wei, K. K. 2003. An integrative study of information systems security effectiveness, International Journal of Information Management 23(2): 139-154. https://doi.org/10.1016/S0268-4012(02)00105-6

Khan, M. F. 1999. Financial modernization in 21st century and challenge for ISLAMIC banking, International Journal of Islamic Financial Services 1(3): 1-4.

Klomp, J.; Haan, J. D. 2012. Banking risk and regulation: does one size fit all?, Journal of Banking and Finance 36(12): 3197-3212. https://doi.org/10.1016/j.jbankfin.2011.10.006

Leach, J. A. 2000. Introduction: modernization of financial institution, The Journal of Corporation Law 25: 681-690.

Leonard, K. J. 1995. The development of a rule based expert system model for fraud alert in consumer credit, European Journal Operational Research 80(2): 350-356. https://doi.org/10.1016/0377-2217(93)E0249-W

Lim, S. H. 2005. Foreign investment impact and incentive: a strategic approach to the relationship between the objectives of foreign investment policy and their promotion, International Business Review 14(1): 61-76. https://doi.org/10.1016/j.ibusrev.2004.12.004

Liou, J. J. H. 2013. New concepts and trends of MCDM for tomorrow - in honor of Professor Gwo-Hshiung Tzeng on the occasion of his $70^{\text {th }}$ birthday, Technological and Economic Development of Economy 19(2): 367-375. https://doi.org/10.3846/20294913.2013.811037

Liou, J. J. H.; Chuang, Y. H.; Tzeng, G. H. 2014. A fuzzy integral-based model for supplier evaluation and improvement, Information Sciences 266(10): 199-217. https://doi.org/10.1016/j.ins.2013.09.025

Liou, J. J. H.; Tamošaitienè, J.; Zavadskas, E. K.; Tzeng, G. H. 2016. New hybrid COPRAS-G MADM Model for improving and selecting suppliers in green supply chain management, International Journal of Production Research 54(1): 114-134. https://doi.org/10.1080/00207543.2015.1010747

Liou, J. J. H; Tzeng, G. H. 2012. Comments on "Multiple criteria decision making (MCDM) methods in economics: an overview", Technological and Economic Development of Economy 18(4): 672-695. https://doi.org/10.3846/20294913.2012.753489

Liu, C. H.; Tzeng, G. H.; Lee, M. H. 2012. Improving tourism policy implantation: the use of hybrid MCDM models, Tourism Management 33(2): 413-426. https://doi.org/10.1016/j.tourman.2011.05.002

Longstaff, F. A. 2010. The subprime credit crisis and contagion in financial markets, Journal of Financial Economics 97(3): 436-450. https://doi.org/10.1016/j.jfineco.2010.01.002

Lu, M. T.; Hu, S. K.; Huang, L. H.; Tzeng, G. H. 2015. Evaluating the implementation of business-to-business m-commerce by SMEs based on a new hybrid MADM model, Management Decision 53(2): 290-317. https://doi.org/10.1108/MD-01-2014-0012 
Lu, M. T.; Lin, S. W.; Tzeng, G. H. 2013. Improving RFID adoption in Taiwan's healthcare industry based on a DEMATEL technique with a hybrid MCDM model, Decision Support Systems 56: 259-269. https://doi.org/10.1016/j.dss.2013.06.006

Lucey, B. M.; Zhang, Q. Y. 2011. Financial integration and emerging markets capital structure, Journal of Banking and Finance 35(5): 1228-1238. https://doi.org/10.1016/j.jbankfin.2010.10.017

Luintel, K. B.; Khan, M.; Arestis, P.; Theodoridis, K. 2008. Financial structure and economic growth, Journal of Development Economics 86: 181-200. https://doi.org/10.1016/j.jdeveco.2007.11.006

Luo, R. 2012. Shanghai as an international financial center - aspiration, reality and implication, Undergraduate Economic Review 8(1): Article 14 [online], [cited 10 August 2014]. Available from Internet: https//digitalcommons.iwu.edu/uer/vol8/iss1/14

Luo, Y. 2011. Study on the current situation of information security and countermeasures in China, Energy Procedia 5: 392-396. https://doi.org/10.1016/j.egypro.2011.03.067

Manson, S.; Zaman, M. 2001. Auditor communication in an evolving environment: going beyond SAS 600 auditors' reports on financial statements, British Accounting Review 33(2): 113-136. https://doi.org/10.1006/bare.2001.0157

Miller, S. 2015. Information and default in consumer credit markets: evidence from a natural experiment, Journal of Financial Intermediation 24(1): 45-70. https://doi.org/10.1016/j.jfi.2014.06.003

Moskow, M. 2002. Financial infrastructure in emerging economies, Journal of Financial Intermediation 11: 354-361. https://doi.org/10.1006/jfin.2002.0347

Muniandy, B.; Ali, M. J. 2012. Development of financial reporting environment in Malaysia, Research in Accounting Regulation 24(2): 115-125. https://doi.org/10.1016/j.racreg.2012.05.004

Ndikumana, L. 2005. Financial development, financial structure, and domestic investment: international evidence, Journal of International Money and Finance 24(4): 651-673. https://doi.org/10.1016/j. jimonfin.2005.03.006

Okuda, H.; Rungsomboon, S. 2006. Comparative cost study of foreign and Thai domestic banks in 1990-2002: its policy implications for a desirable banking industry structure, Journal of Asian Economics 17(4): 714-737. https://doi.org/10.1016/j.asieco.2006.06.012

Opricovic, S.; Tzeng, G. H. 2004. Compromise solution by MCDM methods: a comparative: analysis of VIKOR and TOPSIS, European Journal of Operational Research 156(2): 445-455. https://doi.org/10.1016/S0377-2217(03)00020-1

Opricovic, S.; Tzeng, G. H. 2007. Extended VIKOR method in comparison with outranking methods, European Journal of Operational Research 178(2): 514-529. https://doi.org/10.1016/j.ejor.2006.01.020

Pavía, J. M.; Veres-Ferrer, E. J.; Foix-Escura, G. 2012. Credit card incidents and control systems, International Journal of Information Management 32(6): 501-503. https://doi.org/10.1016/j.ijinfomgt.2012.03.003

Peng, K. H.; Tzeng. G. H. 2013. A hybrid dynamic MADM model for problems-improvement in economics and business, Technological and Economic Development of Economy 19(4): 638-660. https://doi.org/10.3846/20294913.2013.837114

Rana, S. 2012. The Development of the new Chinese banking system: domestic modernization or global financial manipulation? U of Maryland Legal Studies Research Paper No. 2012-7.

Saaty, T. L. 1996. Decision making with dependence and feedback: analytic network process. RWS Publications, Pittsburgh.

Saudagaran, S. M.; Diga, J. G. 2000. The institutional environment of financial reporting regulation in ASEAN, The International Journal of Accounting 35(1): 1-26. https://doi.org/10.1016/S00207063(99)00046-1 
Simon, H. A. 1955. A behavioral model of rational choice, The Quarterly Journal of Economics 69(1): 99-118. https://doi.org/10.2307/1884852

Simon, H. A. 1956. Rational choice and the structure of the environment, Psychological Review 63(2): 129-138. https://doi.org/10.1037/h0042769

Simon, H. A. 1959. Theories of decision-making in economics and behavioral science, The American Economic Review 49(3): 253-283.

Thakor, A. V. 2012. Incentives to innovate and financial crises, Journal of Financial Economics 103(1): 130-148. https://doi.org/10.1016/j.jfineco.2011.03.026

Treacy, W. F.; Carey, M. 2000. Credit risk rating systems at large US banks, Journal of Banking \& Finance 24(1-2): 167-201. https://doi.org/10.1016/S0378-4266(99)00056-4

Tsai, H.; Chang, Y.; Hsiao, P. H. 2011. What drives foreign expansion of the top 100 multinational banks? The role of the credit reporting system, Journal of Banking and Finance 35: 588-605. https://doi.org/10.1016/j.jbankfin.2010.05.016

Tsaih, R.; Liu, Y. J.; Liu, W.; Lien. Y. L. 2004. Credit scoring system for small business loans, Decision Support Systems 38(1): 91-99. https://doi.org/10.1016/S0167-9236(03)00079-4

Tung, S.; Cho, S. 2000. The impact of tax incentives on foreign direct investment in China, Journal of International Accounting, Auditing and Taxation 9(2): 105-135. https://doi.org/10.1016/S1061-9518(00)00028-8

Tzeng, G. H.; Huang, C. Y. 2012. Combined DEMATEL technique with hybrid MCDM methods for creating the aspired intelligent global manufacturing \& logistics systems, Annals of Operations Research 19(1): 7159-7190. https://doi.org/10.1007/s10479-010-0829-4

Tzeng, G. H.; Huang, J. H. 2013. Fuzzy multiple objective decision making. CRC Press, Taylor \& Francis Group, US. https://doi.org/10.1201/b15337

Tzeng, G. H.; Huang, J. J. 2011. Multiple attribute decision making: methods and applications. CRC Press, Taylor \& Francis Group, US.

Von Furstenberg, G. M.; Fratianni, M. 1996. Indicators of financial development, The North American Journal of Economics and Finance 7(1): 19-29. https://doi.org/10.1016/S1062-9408(96)90019-4

Whittaker, C. 2002. The UK financial sector's place in the critical national infrastructure, Information Security Technical Report 7(2): 65-74. https://doi.org/10.1016/S1363-4127(02)02008-3

Yartey, C. A. 2008. Financial development, the structure of capital markets, and the global digital divide, Information Economics and Policy 20(2): 208-227. https://doi.org/10.1016/j.infoecopol.2008.02.002

Yu, C. 2015. Evaluating international financial integration in a center-periphery economy, Journal of International Economics 95(1): 129-144. https://doi.org/10.1016/j.jinteco.2014.10.008

Yu, P. L. 1973. A class of solutions for group decision problem, Management Science 19(8): 936-946. https://doi.org/10.1287/mnsc.19.8.936

Zhao, S. X. B.; Zhang, L.; Wang, D. T. 2004. Determining factors of the development of a national financial center: the case of China, Geoforum 35(5): 577-592. https://doi.org/10.1016/j.geoforum.2004.01.004

Zhiwei, Y.; Zhongyuan, J. 2012. A survey on the evolution of risk evaluation for information systems security, Energy Procedia 17: 1288-1294. https://doi.org/10.1016/j.egypro.2012.02.240 


\section{APPENDIX}

\section{Appendix A: Experts' characteristics in practical experience}

\begin{tabular}{|c|c|c|}
\hline Category & No. & Job title \\
\hline \multirow{12}{*}{$\begin{array}{l}\text { Government officials } \\
\text { from the Guangdong } \\
\text { office, China Banking } \\
\text { Regulatory Commission } \\
\text { (At least } 10 \text { years work } \\
\text { experience on financial } \\
\text { center development) }\end{array}$} & 1 & Chief of Department of State-owned Bank Supervision \\
\hline & 2 & $\begin{array}{l}\text { Chief of Department of Policy Banks and Postal Savings Bank } \\
\text { Supervision }\end{array}$ \\
\hline & 3 & Chief of Department of Non-bank Financial Institutions \\
\hline & 4 & $\begin{array}{l}\text { Chief of Supervision Department of Foreign Financial } \\
\text { Institutions Supervision }\end{array}$ \\
\hline & 5 & Chief of Department of Banking Innovation and Supervision \\
\hline & 6 & $\begin{array}{l}\text { Chief of Department of Banking Information Technology } \\
\text { Supervision }\end{array}$ \\
\hline & 7 & Chief of XX Branch, the Guangdong office \\
\hline & 8 & Chief of XX Branch, the Guangdong office \\
\hline & 9 & Chief of XX Branch, the Guangdong office \\
\hline & 10 & Chief of XX Branch, the Guangdong office \\
\hline & 11 & Chief of XX Branch, the Guangdong office \\
\hline & 12 & Chief of XX Branch, the Guangdong office \\
\hline \multirow{10}{*}{$\begin{array}{l}\text { Presidents or managers } \\
\text { from financial } \\
\text { institutions (More } \\
\text { than } 15 \text { years of work } \\
\text { experience) }\end{array}$} & 13 & Manager of XX Branch, XX Bank \\
\hline & 14 & Manager of XX Branch, XX Bank \\
\hline & 15 & Manager of XX Branch, XX Bank \\
\hline & 16 & President of XX Bank \\
\hline & 17 & President of XX Bank \\
\hline & 18 & Chief of strategy office, XX Bank \\
\hline & 19 & Chief of investment office, XX Bank \\
\hline & 20 & Chief of investment office, XX Securities Corporation \\
\hline & 21 & Manager of XX Securities Corporation \\
\hline & 22 & Manager of XX Securities Corporation \\
\hline \multirow{8}{*}{$\begin{array}{l}\text { Scholars of finance- } \\
\text { related departments (At } \\
\text { least } 10 \text { years of research } \\
\text { experience on financial } \\
\text { center development) }\end{array}$} & 23 & Professor of Department of Accounting \\
\hline & 24 & Professor of Department of Finance and Investment \\
\hline & 25 & Professor of Department of Finance and Investment \\
\hline & 26 & Professor of Department of Finance \\
\hline & 27 & Professor of Department of Management Science \\
\hline & 28 & Professor of Department of Business Administration \\
\hline & 29 & Senior Researcher \\
\hline & 30 & Senior Researcher \\
\hline
\end{tabular}




\section{Appendix B: Questionnaire}

The second step questionnaire

Improving China's Regional Financial Center Modernization Development Using a New Hybrid MADM Model

Good day! This is an academic research about "Improving China's Regional Financial Center Modernization Development Using a New Hybrid MADM Model”. The purpose is to improve regional financial center modernization improvement strategies, as well as key factors related to performance evaluation.

As we are greatly impressed by your excellent accomplishment in this field, if we could have the honor of receiving your valuable opinions, the result and reliability of the study will be extremely benefited. The information you provide is for academic statistical analysis only, and will not be separately announced to the outside or transferred to other applications. Therefore, please fill out the answers at ease.

Your support will be a key to the successful completion of the study. We are looking forward to the benefits if would take the time to express your opinions to be taken as reference for this study. Please accept our most sincere gratitude. Thank you very much.

\section{B1. Instructions for filling out the questionnaire}

This questionnaire is divided into six parts:

1) Instructions for completion;

2) Descriptions of dimensions and criteria;

3) Method for completion;

3.1) Comparison of the impact of the four dimensions;

3.2) Comparison of the impact of the 14 standards;

3.3) Performance evaluation of the 14 standards;

4) Personal data.

\section{B2. Descriptions of dimensions and criteria}

\begin{tabular}{lll}
\hline \multicolumn{1}{c}{ Dimension } & \multicolumn{1}{c}{ Criteria } & \multicolumn{1}{c}{ Descriptions } \\
\hline $\begin{array}{l}\text { Government } \\
\text { policy }\end{array}$ & $\begin{array}{l}\text { Financial industry } \\
\text { development policy }\end{array}$ & $\begin{array}{l}\text { Including the financial incentive system, tax } \\
\text { abatements, and tax credits for enterprises, as } \\
\text { promoted by the Guangzhou government; }\end{array}$ \\
\cline { 2 - 3 } & $\begin{array}{l}\text { Financial supervision and } \\
\text { regulation }\end{array}$ & $\begin{array}{l}\text { Financial administrative authorities monitoring } \\
\text { financial transactions and maintaining financial } \\
\text { market stability; }\end{array}$ \\
\cline { 2 - 3 } & $\begin{array}{l}\text { Allocation of financial } \\
\text { resources }\end{array}$ & $\begin{array}{l}\text { The central and local governments inject funds } \\
\text { into the financial sector. }\end{array}$ \\
\hline
\end{tabular}




\begin{tabular}{|c|c|c|}
\hline Dimension & Criteria & Descriptions \\
\hline \multirow[t]{4}{*}{$\begin{array}{l}\text { Financial } \\
\text { infrastructure } \\
\text { and safety }\end{array}$} & Financial infrastructure & $\begin{array}{l}\text { Include convenient transportation and } \\
\text { communication, and good capital flow } \\
\text { environment; }\end{array}$ \\
\hline & $\begin{array}{l}\text { Financial ecological } \\
\text { environment }\end{array}$ & $\begin{array}{l}\text { Refers to the legal system, social honesty, and } \\
\text { credit, the accounting and auditing standards, } \\
\text { the intermediary service system, and the } \\
\text { relationship between banks and firms; }\end{array}$ \\
\hline & Credit systems & $\begin{array}{l}\text { Build division and enterprise credit systems; } \\
\text { establish financial credit infrastructure } \\
\text { and systems; construct credit records, } \\
\text { credit evaluation, credit monitoring, credit } \\
\text { information disclosure and penalization } \\
\text { systems, etc.; }\end{array}$ \\
\hline & $\begin{array}{l}\text { Electronic financial and } \\
\text { information safety }\end{array}$ & $\begin{array}{l}\text { Enhance electronic financial transaction } \\
\text { information security. }\end{array}$ \\
\hline \multirow[t]{3}{*}{$\begin{array}{l}\text { Financial } \\
\text { service }\end{array}$} & Credit market & $\begin{array}{l}\text { Find a perfect credit market, such as loan } \\
\text { institutions to SMEs; }\end{array}$ \\
\hline & Financial structure & $\begin{array}{l}\text { Whether or not Guangzhou financial industry } \\
\text { (banking, insurance and security) development } \\
\text { is unbalanced; }\end{array}$ \\
\hline & $\begin{array}{l}\text { National financial market } \\
\text { trading platform }\end{array}$ & $\begin{array}{l}\text { Establish a national financial market trading } \\
\text { platform, such as the Guangzhou trade center } \\
\text { in financial assets and foreign exchange market. }\end{array}$ \\
\hline \multirow{3}{*}{$\begin{array}{l}\text { Financial } \\
\text { institutions } \\
\text { and human } \\
\text { resources }\end{array}$} & Large financial institutions & $\begin{array}{l}\text { Establish global and domestic influential } \\
\text { financial institutions or introduce foreign } \\
\text { financial institutions; }\end{array}$ \\
\hline & New financial institutions & Set up a variety of new financial institutions; \\
\hline & $\begin{array}{l}\text { Listed financial enterprises } \\
\text { Financial employees' morality }\end{array}$ & $\begin{array}{l}\text { Increase the number of finance-related } \\
\text { companies listed in Guangzhou. } \\
\text { The quality and morality of financial } \\
\text { professionals include CEO, managers, and staff. }\end{array}$ \\
\hline
\end{tabular}

\section{B3. Method for completion}

To complete the survey method and description, as follows:

Respond to the level of importance and performance of each criterion, according to experts' opinions in practical experience; enter the scales specified for importance (choosing important criteria) and performance (using evaluation and improvement) by natural language.

\section{B3.1. Comparison of the impact of the four dimensions}

Instructions for completing the index: No impact (0); Low impact (1); Medium impact (2); High impact (3); Very high impact (4). 
Example: The impact of A on B is very high, thus, "4" is filled out at the corresponding position.

\begin{tabular}{lllllll}
\hline & $\mathrm{A}$ & $\mathrm{B}$ & $\mathrm{C}$ & $\mathrm{D}$ & $\mathrm{E}$ \\
\hline $\mathrm{A}$ & 4 & $\bigcirc$ & & & \\
\hline $\mathrm{B}$ & & 4 & & & \\
\hline
\end{tabular}

Real case description

1) The impact of government policy on financial infrastructure and safety is "Very high"; therefore, $\mathbf{4}$ is entered in the box;

2) The impact of financial infrastructure and safety on financial institutions and human resources is "High"; therefore, $\mathbf{3}$ is entered in the box.

\begin{tabular}{|c|c|c|c|c|}
\hline Dimensions & 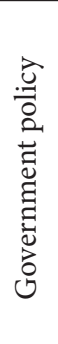 & 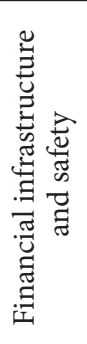 & 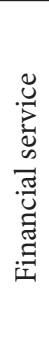 & 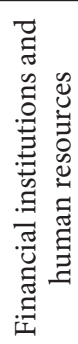 \\
\hline Government policy & & 4 & & \\
\hline Financial infrastructure and safety & & & & 3 \\
\hline \multicolumn{5}{|l|}{ Financial service } \\
\hline Financial institutions and human re & & & & \\
\hline
\end{tabular}

Please complete the comparison level of four dimensions in the following table

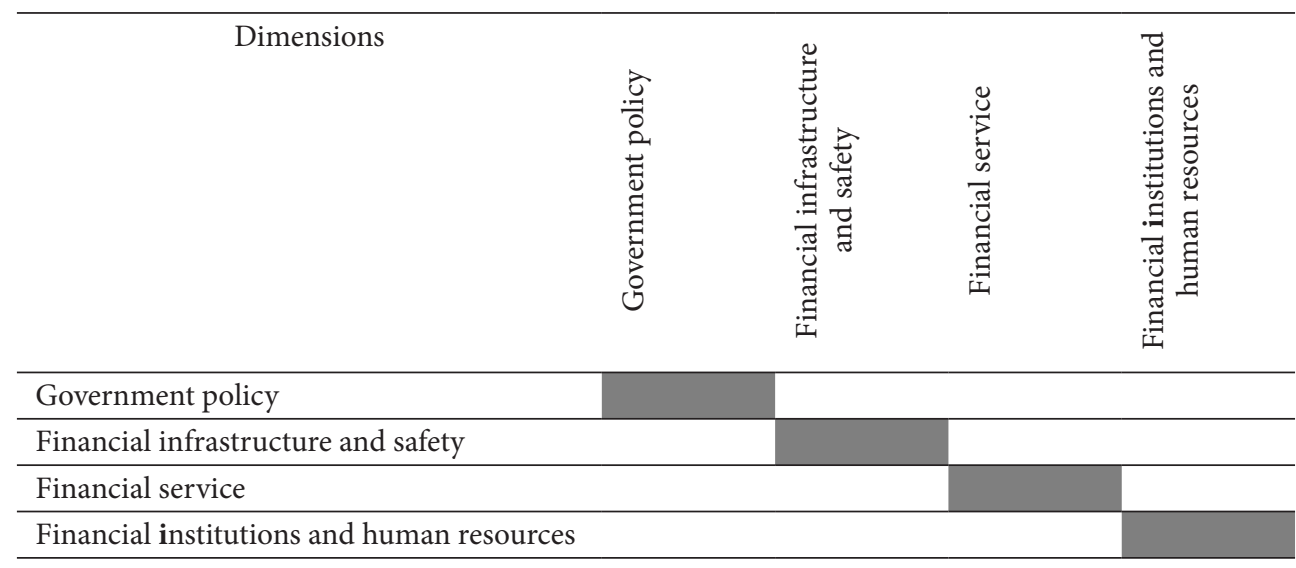

Instructions for completion of the index: No impact (0); Low impact (1); Medium impact (2); High impact (3); Very high impact (4). 
B3.2. Comparison of the impact of the $\mathbf{1 4}$ standards (Please complete the compared levels of 14 criterions in the following table)

\begin{tabular}{|c|c|c|c|c|c|c|c|c|c|c|c|c|c|c|}
\hline : & 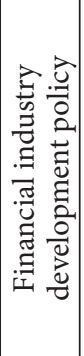 & 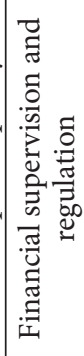 & 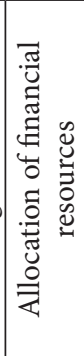 & 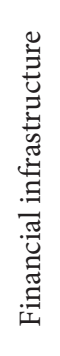 & 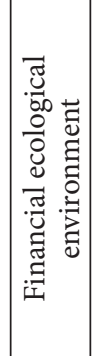 & 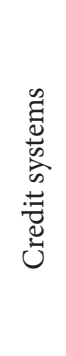 & 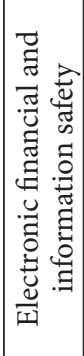 & 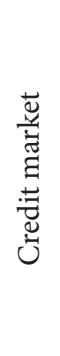 & 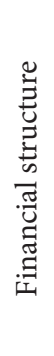 & 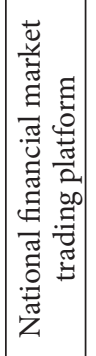 & 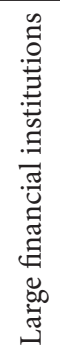 & 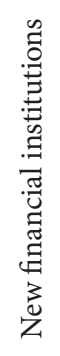 & 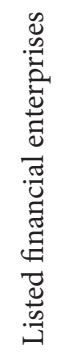 & 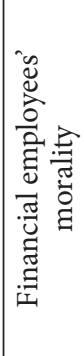 \\
\hline $\begin{array}{l}\text { Financial industry } \\
\text { development policy }\end{array}$ & & & & & & & & & & & & & & \\
\hline $\begin{array}{l}\text { Financial supervision } \\
\text { and regulation }\end{array}$ & & & & & & & & & & & & & & \\
\hline $\begin{array}{l}\text { Allocation of financial } \\
\text { resources }\end{array}$ & & & & & & & & & & & & & & \\
\hline $\begin{array}{l}\text { Financial } \\
\text { infrastructure }\end{array}$ & & & & & & & & & & & & & & \\
\hline $\begin{array}{l}\text { Financial ecological } \\
\text { environment }\end{array}$ & & & & & & & & & & & & & & \\
\hline Credit systems & & & & & & & & & & & & & & \\
\hline $\begin{array}{l}\text { Electronic financial } \\
\text { and information safety }\end{array}$ & & & & & & & & & & & & & & \\
\hline Credit market & & & & & & & & & & & & & & \\
\hline Financial structure & & & & & & & & & & & & & & \\
\hline $\begin{array}{l}\text { National financial } \\
\text { market trading } \\
\text { platform }\end{array}$ & & & & & & & & & & & & & & \\
\hline $\begin{array}{l}\text { Large financial } \\
\text { institutions }\end{array}$ & & & & & & & & & & & & & & \\
\hline $\begin{array}{l}\text { New financial } \\
\text { institutions }\end{array}$ & & & & & & & & & & & & & & \\
\hline $\begin{array}{l}\text { Listed financial } \\
\text { enterprises }\end{array}$ & & & & & & & & & & & & & & \\
\hline $\begin{array}{l}\text { Financial employees' } \\
\text { morality }\end{array}$ & & & & & & & & & & & & & & \\
\hline
\end{tabular}

Instructions for completing the index: No impact (0); Low impact (1); Medium impact (2); High impact (3); Very high impact (4). 


\section{B3.3. Survey of the improvability level of the performance evaluation factors}

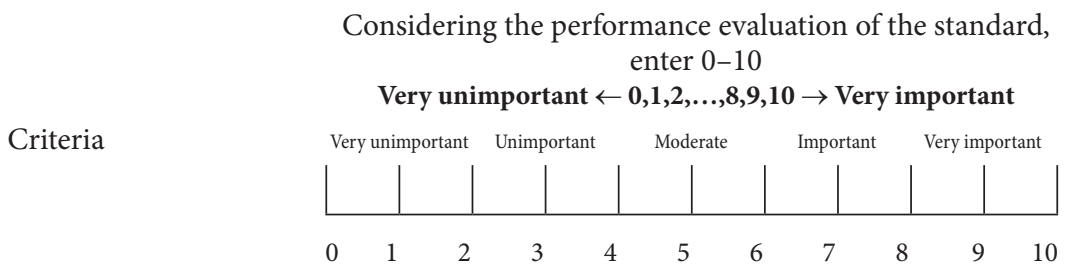

\begin{tabular}{l}
\hline Financial industry development policy \\
\hline Financial supervision and regulation \\
\hline Allocation of financial resources \\
\hline Financial infrastructure \\
\hline Financial ecological environment \\
\hline Credit systems \\
\hline $\begin{array}{l}\text { Electronic financial and information } \\
\text { safety }\end{array}$ \\
\hline Credit market \\
\hline Financial structure \\
\hline $\begin{array}{l}\text { National financial market trading } \\
\text { platform }\end{array}$ \\
\hline Large financial institutions \\
\hline New financial institutions \\
\hline Listed financial enterprises \\
\hline Financial employees' morality
\end{tabular}

\section{B4. Basic personal data}

1. Gender: $\square$ Male $\square$ Female

2. Education Level: $\square$ College $\square$ University $\quad \square$ Master $\square$ Ph.D.

3. Service Unit: . 4. Service Dept.: . 5. Job Title:
6. Age: $\square$ Under 30 years old (including)

$\square 41 \sim 50$ years old $\square$ Over 50 years old

Kuang-Hua HU. He is an Assistant Professor in the Department of Accounting, Guangdong University of Finance and Economics, 21 Chisha Road, Haizhu District, Guangzhou 510320 PRC. His researches interests include Multiple Criteria Decision Making (MCDM), performance evaluation and economic development, etc. He has publications in Journal of Testing and Evaluation and Journal of Information and Optimization Sciences.

Wei JIANGUO. He is Associate Professor and Chairman at the Department of Accounting, Nanfang College of Sun Yat-Sen University in China. His research field focuses on auditing and efficiency. His has published 30 referred papers in academic journals, projects and books.

Gwo-Hshiung TZENG. He was born in 1943 in Taiwan. In 1967, he received the Bachelor's degree in business management from the Tatung Institute of Technology (now Tatung University), Taiwan; in 1971, 
he received the Master's degree in urban planning from Chung Hsing University (Now Taipei University), Taiwan; and in 1977, he received the PhD degree course in management science from Osaka University, Osaka, Japan.

He was an Associate Professor at Chiao Tung University, Taiwan, from 1977 to 1981, a Research Associate at Argonne National Laboratory from July 1981 to January 1982, a Visiting Professor in the Department of Civil Engineering at the University of Maryland, College Park, from August 1989 to August 1990, a Visiting Professor in the Department of Engineering and Economic System, Energy Modeling Forum at Stanford University, from August 1997 to August 1998, a Professor at Chaio Tung University from 1981 to 2003, and a Chair Professor at Chiao Tung University. He got National Distinguished Chair Professor (Highest Honor offered by the Ministry of Education Affairs, Taiwan) and Distinguished Research Fellow (Highest Honor Offered by NSC, Taiwan) from 2000. His current research interests include statistics, multivariate analysis, network, routing and scheduling, multiple criteria decision making, fuzzy theory, hierarchical structure analysis for applying to technology management, energy, environment, transportation systems, transportation investment, logistics, location, urban planning, tourism, technology management, electronic commerce, global supply chain, etc. He got Highly Cited Paper (March 13, 2009) ESI "Compromise solution by MCDM methods: A comparative analysis of VIKOR and TOPSIS" as published in the "EUROPEAN JOURNAL OF OPERATIONAL RESEARCH" on $16^{\text {th }}$ July 2004, 156(2): $445-455$, has been recently identified by Thomson Reuters' Essential Science Indicators SM to be one of the most cited papers in the field of Economics.

He has got the MCDM Edge worth-Pareto Award by International Society on Multiple Criteria Decision Making (June 2009), has got the Pinnacle of Achievement Award 2005 of the world, and had got the national distinguished chair professor and award (highest honor offered) of the Ministry of Education Affairs of Taiwan and three times of distinguished research award and two times of distinguished research fellow (highest honor offered) of National Science Council of Taiwan. Fellow IEEE Member (From September 30, 2002). He organized a Taiwan affiliate chapter of the International Association of Energy Economics in 1984 and he was the Chairman of the Tenth International Conference on Multiple Criteria Decision Making, 19-24 July 1992, in Taipei; the Co-Chairman of the 36th International Conference on Computers and Industrial Engineering, 20-23 June 2006, Taipei, Taiwan; the Chairman of the International Summer School on Multiple Criteria Decision Making, 2-14 July 2006, Kainan University, Taiwan. He is a member of IEEE, IAEE, ISMCDM, World Transport, the Operations Research Society of Japan, the Society of Instrument and Control Engineers Society of Japan, the City Planning Institute of Japan, the Behavior metric Society of Japan, the Japan Society for Fuzzy Theory and Systems; and participating many Society of Taiwan. 